NBER WORKING PAPER SERIES

\title{
MEETING URBAN HOUSING NEEDS: DO PEOPLE REALLY COME TO THE NUISANCE?
}

\author{
Brooks M. Depro \\ Christopher Timmins \\ Maggie O'Neil \\ Working Paper 18109 \\ http://www.nber.org/papers/w18109 \\ NATIONAL BUREAU OF ECONOMIC RESEARCH \\ 1050 Massachusetts Avenue \\ Cambridge, MA 02138
}

May 2012

The authors gratefully acknowledge helpful comments and suggestions received from H. Spencer Banzhaf, as well as from seminar participants at the University of Kentucky, the University of Maryland AREC, Resources for the Future, Texas A\&M, Rice University, and the University of Houston. Brooks Depro and Maggie O'Neil gratefully acknowledge funding from RTI International's Annual Professional Development Award program. The views expressed herein are those of the authors and do not necessarily reflect the views of the National Bureau of Economic Research.

NBER working papers are circulated for discussion and comment purposes. They have not been peerreviewed or been subject to the review by the NBER Board of Directors that accompanies official NBER publications.

(C) 2012 by Brooks M. Depro, Christopher Timmins, and Maggie O'Neil. All rights reserved. Short sections of text, not to exceed two paragraphs, may be quoted without explicit permission provided that full credit, including $\odot$ notice, is given to the source. 
Meeting Urban Housing Needs: Do People Really Come to the Nuisance?

Brooks M. Depro, Christopher Timmins, and Maggie O'Neil

NBER Working Paper No. 18109

May 2012

JEL No. Q5,Q52,Q53,R3

\begin{abstract}
Understanding the forces that lead to correlations between pollution exposure, poverty, and race is crucial to the formation of sound environmental justice (EJ) policy. In particular, what are the roles of disproportionate siting of pollution sources versus post-siting housing market dynamics (e.g., "white flight")? Empirical analysis of post-siting dynamics has yielded mixed evidence. We demonstrate that this is because the models traditionally used to analyze it are not capable of identifying individual responses to pollution exposure. We address this limitation in two ways. First, we show how additional structure can be used along with traditional EJ data to recover behavioral parameters describing market dynamics. Second, we show how market dynamics can be directly observed using a new and distinctive data set that describes the decisions of individual homebuyers and details their circumstances (including pollution exposure) both before and after their moves. An application of the first approach shows that whites are more likely to flee TRI exposure in Los Angeles County than are other minority groups - particularly Hispanics, who constitute a plurality and the largest group of people of color. The second approach shows that whites are both more likely to flee and less likely to come to the nuisance, compared with all other groups (particularly Hispanics). Importantly, these results contrast with those of a traditional EJ analysis, which fails to provide any consistent evidence of post-siting dynamics. If the moving patterns we recover with our two models persist over time, we would expect to see higher percentages of minority residents (particularly Hispanics) living in closer proximity to L.A. County TRI plants, lending support to the post-siting market dynamics hypothesis.
\end{abstract}

Brooks M. Depro

RTI International

3040 Cornwallis Road

RTP, NC 27709-2194

bmd@rti.org

Christopher Timmins

Department of Economics

Duke University

209 Social Sciences Building

P.O. Box 90097

Durham, NC 27708-0097

and NBER

christopher.timmins@duke.edu

\author{
Maggie O'Neil \\ RTI International \\ 3040 Cornwallis Road \\ RTP, NC 27709-2194 \\ maggieo@rti.org
}




\section{INTRODUCTION}

Two decades after its historic study, the United Church of Christ (2007) reported that over five million people of color live within one mile of a hazardous waste facility.

Understanding the social forces behind this outcome influences how we interpret such studies, assess policies designed to change existing associations between race and hazardous waste, and determine how cleanup activities will benefit different groups of people (Banzhaf 2011). For nearly two decades, researchers have sought to better understand two competing explanations for this observed correlation between race, income, and pollution. In particular, is it the result of disproportionate (possibly discriminatory) siting of landfills, hazardous waste facilities, sources of toxic emissions, and other "locally undesirable land uses" (LULU's)? Or, is it the result of housing market dynamics that follow siting? If it is the latter, then even equitable site placement will be undone when those (typically white) residents with the means to move away from a LULU do so, and their homes are re-populated by lower income (typically minority) residents (Been 1994). In this paper, we demonstrate that previous models used to recover evidence of post-siting market dynamics have been unidentified, and we provide two alternative empirical approaches to recovering such evidence. With those alternative approaches, we find strong evidence of market dynamics as an explanation for observed correlations between race, income, and pollution exposure.

Learning about the tradeoffs made by individual homebuyers is particularly important for understanding the motivations that drive the market dynamics story. Each year, more than 30 million people move from one home to another (US Bureau of the Census 2011a). The most common reason given for changing homes is the need for more living space or a better neighborhood; this is especially true for moves made within a county (US Census Bureau 
2011b). Although additional living space and better neighborhoods can be purchased by reallocating expenditures toward housing structure and neighborhood quality and reducing consumption of other goods, homebuyers do have alternatives. For example, a homebuyer might choose a home that is located near a hazardous waste site or other LULU - this behavior has typically been referred to as "coming to a nuisance" (Been 1994) or "minority move-in" (Morello-Frosch et al. 2002), depending upon the race of the homebuyer. A model of utility maximizing households trading-off housing stock, neighborhood quality, and other (dis)amenities is at the heart of most residential sorting models (see Kuminoff, Smith and Timmins (2010) for an overview) and could explain "coming to the nuisance" as a rational response to opportunities in the housing marketplace. However, properly measuring the tradeoffs made by different groups of homebuyers requires knowing their circumstances both before and after their moves.

Without "before and after" data, finding evidence of the market dynamics hypothesis (both "fleeing the nuisance" by some groups and "coming to the nuisance" by others) has proven elusive. In this paper, we argue that it is, in fact, not possible to identify these market dynamics using geographically aggregated (e.g. census tract) data on population flows in an unstructured model like that typically found in the EJ literature.

We address this problem in two ways. Our first approach combines modeling structure with typically available aggregate data to achieve identification, providing a method that could be easily adapted by other researchers working with similar data. That approach yields evidence suggesting that white (and, to a lesser extent, black and Asian) "flight" characterizes post-siting market dynamics, leading to long-run exposure inequities (particularly for Hispanics). 
Our second approach uses individual household choices. In particular, we use proprietary information to construct a new and distinctive data set that allows us to look directly at the preand post-move circumstances of individual homebuyers. From these decisions, we are able to learn whether different groups are more or less likely to come to or flee from a nuisance (in our case, toxic emissions). We can also begin assessing the tradeoffs between housing services, neighborhood quality, and pollution exposure that arise from those moves. Despite the dramatic differences in data and method, the results of this analysis confirm those found in the structural model.

This paper proceeds as follows. Section 2 reviews the EJ literature that has sought to distinguish the competing roles of market dynamics and inequitable siting, and explains why the approach typically used to recover the role of post-siting market dynamics is not actually able to do so. Section 3 describes the "nuisance" we will use in our empirical application - exposure to plants listed in the EPA's Toxic Release Inventory in L.A. County. Section 4 describes the two data sets that we use. The first is a census tract-level data set similar to what has been typically used in the EJ literature. The second is a unique "buyer panel", which allows us to follow individual homebuyers as they move from one location to another. Section 5 uses the tract-level data to estimate both a traditional EJ model of market dynamics and our structural model. Section 6 uses the buyer panel data to directly test the market dynamics hypothesis. Section 7 concludes. 


\section{UNRAVELING THE CAUSES OF RACE-INCOME-POLLUTION CORRELATION}

\subsection{Previous Research}

A number of early longitudinal studies found little or no evidence that aggregate demographic changes occurred after the siting of hazardous waste storage and disposal facilities (Oakes, Anderton, and Anderson 1996; Been and Gupta 1997; Shaikh and Loomis 1999; Pastor, Sadd, and Hipp 2001; Morello-Frosch et al. 2002). The study by Pastor, Sadd, and Hipp (2001), like our analysis, focuses on L.A. County. Like most other studies, it adopts a geographically aggregated (census tract) approach and uses multivariable regression and simultaneous equation methods to conclude that disproportionate facility siting provides a better explanation for the correlation between race and proximity to toxic storage and disposal facilities. Pastor, Sadd, and Hipp also express reservations about housing market-driven mobility explanations because the reasoning can imply that people of color have different preferences for risk than whites. On the other hand, they do concede that alternative explanations such as housing market discrimination could help to explain the correlation between race and pollution.

Some recent assessments of residential choice behavior do provide persuasive evidence in favor of housing market dynamics. Using geographically aggregated choices, Cameron and McConnaha (2006) examine environmentally motivated migration near four Superfund sites. Similarly, Banzhaf and Walsh (2008) use a model based on Epple, Filimon, and Romer (1984) to predict that communities experiencing reductions in TRI emissions will see increases in total population. Additionally, they predict that increases in air pollution levels will encourage higher income households to exit a community, whereas lower income households will be more likely to enter. However, Banzhaf and McCormick (2007) demonstrate that similar predictions cannot be made about neighborhood-level race variables when homebuyers have heterogeneous 
preferences. Banzhaf and Walsh (2010) demonstrate that predictions become even more complicated when homebuyers have preferences for the race of their neighbors.

\subsection{Non-Identification in the Traditional Model of Housing Market Dynamics}

In the absence of clear theoretical predictions about the response of race to pollution, diagnosing market dynamics becomes an empirical question. This is, however, an empirical question that aggregate data alone are not able to answer. In particular, changes in census tract demographics cannot be taken as evidence for or against the hypotheses of "white flight" or that people of color "come to the nuisance" to meet housing needs.

We illustrate this with a simple example. Consider a city with just three locations $(j=1$,

$2,3)$ observed in each of two time periods $(t=\mathrm{A}, \mathrm{B})$. We use $\operatorname{pop}_{j}^{t}$ to measure the population in location $j$ in period $t^{2} s_{j, k}$ is used to denote the share of individuals in location $k$ in period A who choose to reside in location $j$ in period $\mathrm{B}$. The market dynamics associated with this collection of locations are described by the following system of equations:

$$
\left(\begin{array}{lll}
s_{1,1} & s_{1,2} & s_{1,3} \\
s_{2,1} & s_{2,2} & s_{2,3} \\
s_{3,1} & s_{3,2} & s_{3,3}
\end{array}\right)\left(\begin{array}{c}
\operatorname{pop}_{1}^{A} \\
\operatorname{pop}_{2}^{A} \\
\operatorname{pop}_{3}^{A}
\end{array}\right)=\left(\begin{array}{c}
\operatorname{pop}_{1}^{B} \\
\operatorname{pop}_{2}^{B} \\
\operatorname{pop}_{3}^{B}
\end{array}\right)
$$

A traditional EJ analysis considers the change in the population of a particular sub-group in each location $j$ (i.e., $\Delta p o p_{j}=p o p_{j}^{B}-p o p_{j}^{A}$ ) and compares it to either the initial exposure to the

\footnotetext{
2 In most EJ analyses, pop $_{j}^{t}$ will refer to the population of a particular race or income sub-group (e.g., low-income minorities). Without loss of generality, we refer to a single population group in this example.
} 
environmental amenity $\left(\alpha_{j}^{A}\right)$ or to the change in exposure to the amenity in that location $\left(\alpha_{j}^{B}-\alpha_{j}^{A}\right) . \frac{\Delta p o p_{j}}{\alpha_{j}^{A}}>0$ is taken as evidence that members of the sub-group in question "flee the nuisance" (i.e., come to the amenity).

The first point to make is that one should not draw that conclusion from this observation. Rather, the individual behavior of "coming to" or "fleeing from" the nuisance is described by the elements of the matrix $\left[s_{j, k}\right]-$ specifically, by the way in which $s_{j, k}$ co-varies with the change in exposure associated with the move from $k$ to $j\left(\Delta \alpha_{j, k}\right)$. This will directly measure how the change in exposure associated with a move affects the tendency of individuals to make that move. If increasing pollution exposure makes a move more likely for members of a particular subgroup, this suggests that this sub-group "comes to the nuisance".

Mathematically, we show that the change in population vectors over time does not identify $\left[s_{j, k}\right]$ Since

$$
\sum_{j} s_{j, k}=1 \quad \forall k=1,2,3
$$

equations (1) and (2) constitute a system of six equations with nine unknown values of $s_{j, k}$. The system is, therefore, under-identified. Put differently, without additional structure, there is not a unique $\left[s_{j, k}\right]$ matrix that can explain the observed changes in aggregate populations. 
Next, we illustrate the point with a series of examples. In each, we consider a different $\left[s_{j, k}\right]$ matrix, but maintain the same distribution of amenity levels: $\alpha_{1}=1, \alpha_{2}=-0.5, \alpha_{3}=0$.

To simplify the story, we hold these amenity levels constant as we move from period A to period

B. Finally, in each of the first two examples, $\left[s_{j, k}\right]$ is constructed to yield the same changes to population in each location $\Delta p o p_{1}: 3 \rightarrow 1.8, \Delta p o p_{2}: 2 \rightarrow 2.2, \Delta p o p_{3}: 1 \rightarrow 2$. However, considering the conditional correlation between $s_{j, k}$ and $\Delta \alpha_{j, k}$, we find very different implications for market dynamics. After each example, we report the slope coefficient estimate from the regression of $s_{j, k}$ on $\Delta \alpha_{j, k}$ and an intercept:

\section{Example \#1:}

$$
\left(\begin{array}{lll}
0.00 & 0.60 & 0.60 \\
0.50 & 0.25 & 0.20 \\
0.50 & 0.15 & 0.20
\end{array}\right)\left(\begin{array}{l}
3 \\
2 \\
1
\end{array}\right)=\left(\begin{array}{l}
1.8 \\
2.2 \\
2.0
\end{array}\right) \quad\left(\begin{array}{l}
\alpha_{1}^{A} \\
\alpha_{2}^{A} \\
\alpha_{3}^{A}
\end{array}\right)=\left(\begin{array}{c}
\alpha_{1}^{B} \\
\alpha_{2}^{B} \\
\alpha_{3}^{B}
\end{array}\right)=\left(\begin{array}{c}
-1 \\
-0.5 \\
0
\end{array}\right)
$$

$$
\text { Slope coefficient }=-0.0583 \text { (Coming to the Nuisance) }
$$

\section{Example \#2:}

$$
\left(\begin{array}{lll}
0.50 & 0.10 & 0.10 \\
0.30 & 0.50 & 0.30 \\
0.20 & 0.40 & 0.60
\end{array}\right)\left(\begin{array}{l}
3 \\
2 \\
1
\end{array}\right)=\left(\begin{array}{l}
1.8 \\
2.2 \\
2.0
\end{array}\right) \quad\left(\begin{array}{l}
\alpha_{1}^{A} \\
\alpha_{2}^{A} \\
\alpha_{3}^{A}
\end{array}\right)=\left(\begin{array}{c}
\alpha_{1}^{B} \\
\alpha_{2}^{B} \\
\alpha_{3}^{B}
\end{array}\right)=\left(\begin{array}{c}
-1 \\
-0.5 \\
0
\end{array}\right)
$$

Slope coefficient $=0.0833$ (Fleeing the Nuisance)

\footnotetext{
${ }^{3}$ Even with this simplification, individuals will still experience a change in the amenity when moving from one location to another. This simplification is also consistent with much of the literature, which describes the change in population over a period as a function of the attributes of locations (e.g., exposure to TSDF's) at the start of that period.
} 
Both examples are characterized by the same aggregate population dynamics, which a traditional EJ analysis would construe as fleeing the nuisance (i.e., population falls in the low-amenity community and rises in the high-amenity community). However, the individual market dynamics underlying Example \#1 reflect "coming to the nuisance" (i.e., an improvement in the amenity makes a particular move less likely), while those underlying Example \#2 reflect "fleeing the nuisance" (i.e., an improvement in the amenity makes the move more likely).

In our final example, we illustrate a case that is particularly relevant for the EJ literature. Example \#3 describes a situation in which the aggregate population distribution does not change at all between periods 1 and 2; however, the correlation between $s_{j, k}$ and $\Delta \alpha_{j, k}$ reveals market dynamics consistent with "coming to the nuisance".

Example \#3: No Change in Aggregate Population Distribution

$$
\begin{gathered}
\left(\begin{array}{lll}
0.80 & 0.20 & 0.20 \\
0.10 & 0.70 & 0.30 \\
0.10 & 0.10 & 0.50
\end{array}\right)\left(\begin{array}{l}
3 \\
2 \\
1
\end{array}\right)=\left(\begin{array}{l}
3 \\
2 \\
1
\end{array}\right) \quad\left(\begin{array}{c}
\alpha_{1}^{A} \\
\alpha_{2}^{A} \\
\alpha_{3}^{A}
\end{array}\right)=\left(\begin{array}{c}
\alpha_{1}^{B} \\
\alpha_{2}^{B} \\
\alpha_{3}^{B}
\end{array}\right)=\left(\begin{array}{c}
-1 \\
-0.5 \\
0
\end{array}\right) \\
\text { Slope coefficient }=-0.0833 \text { (Coming to the Nuisance) }
\end{gathered}
$$

A typical result in EJ papers seeking evidence of market dynamics is to find that population distributions do not exhibit a statistically significant response to the placement of environmental nuisances. This final example shows that this outcome is consistent with important underlying market dynamics at the level of the individual. 
These examples make clear that aggregate population dynamics alone are not able to distinguish the change in circumstances individuals face when moving. We show below that this is a problem that can be addressed with either (1) additional modeling structure applied to aggregate data, or (2) microdata describing individual homebuyer circumstances both before and after a move.

\subsection{Individual Homebuyers}

We will demonstrate that one solution to the problem of recovering estimates of market dynamics uses microdata describing the moving decisions of particular homebuyers. Crowder and Downey (2010) conducted one of the first analyses to use individual-level choice data to examine proximity to pollution (TRI emissions measured at the census tract level), propensity to move, and the neighborhoods chosen by black and Latino households. Their study found that, when they move, black and Latino households tend to move into neighborhoods with significantly higher TRI emissions than comparable white households, suggesting a dynamic that would lead to disproportionate pollution exposure by race. While Crowder and Downey provide an important insight, their analysis leaves a pair of questions unresolved.

First, how does an individual's pollution exposure actually change when that individual moves? While minority households may be more likely to purchase houses in neighborhoods with high exposure to pollution, they are also more likely to be moving from polluted neighborhoods. Seeing an individual purchase a house two miles from a TRI site implies something very different about market dynamics if that individual is coming from a house that is one mile from a site versus a house ten miles from a site. Consequently, independently 
examining the attributes of either the houses purchased or the houses sold by different groups will not describe the changes in exposure generated by household moves.

Second, what do people give up when purchasing a new house? Do minority households take on more exposure to pollution in order to acquire more housing services or higher quality neighborhood attributes? Do they do so in order to reduce overall housing expenditures so as to be able to increase other forms of consumption or savings? While this is a separate question from that of whether moves are responsible for increased exposure, it is a relevant concern if we seek policies to address that mechanism. Directly answering this question will require observing the individual's full slate of circumstances before and after moving.

\section{EPA TOXIC RELEASE INVENTORY PROGRAM}

In response to the problems caused by high-profile toxic chemical releases ${ }^{4}$, Congress enacted the Emergency Planning and Community Right to Know Act (EPCRA) in 1986. To meet requirements under Section 313 of the Act, the EPA was required to collect information from industrial facilities that would help facilitate emergency planning and provide the public with information on releases of toxic chemicals in their communities. Congress later expanded the Toxic Release Inventory (TRI) program as part of Pollution Prevention Act of 1990. According to the EPA, the existing TRI database includes information on approximately 650 chemicals and chemical categories that are managed by over 20,000 industrial and other facilities. Despite some concerns over the self-reporting aspects of the program, ${ }^{5}$ the TRI

\footnotetext{
${ }^{4}$ For example, the 1984 Union Carbide plant's toxic gas release in Bhopal India.

${ }^{5}$ Previous studies have found some evidence of air emissions underreporting (de Marchi and Hamilton 1996; Koehler and Spengler 2007).
} 
continues to provide one of the richest sources of information about facilities that may be considered environmental nuisances (Natan and Miller 1998).

We identified the locations of regulated facilities by using information that the EPA makes available through the TRI Data Files and Tools webpage. ${ }^{6}$ Using ESRI's ARCGIS mapping and spatial analysis software, we were able to identify the number of TRI facilities located within one mile of each Census tract using the tract centroid as the point of reference. Similarly, we used the geographic coordinates for the individual houses to identify the number of TRI facilities located within one mile of each home.

Between 1990 and 1997, there were two substantial changes in TRI reporting requirements that influenced the population of facilities included in EPA data files. In 1993, the EPA added over 286 chemicals to the TRI reporting program. In 1997, the EPA added seven industrial sectors to TRI: metal mining, coal mining, electrical utilities that combust coal and/or oil, hazardous waste treatment and disposal facilities, chemical wholesale distributors, petroleum bulk stations and terminals, and solvent recovery services. As a result of these changes, we restrict our sample to the years 1998 to 2008, when TRI facility entry/exit was less likely to have been driven by changes in reporting requirements. During this period, EPA deleted phosphoric acid (2000) and reduced reporting thresholds for lead and lead compounds (2001). To minimize the possibility that year-to-year facility entry/exit was driven by these two reporting requirement changes, we eliminated a small number of TRI facilities that only produced phosphoric acid or lead and lead compounds.

One of the most common and easiest ways to examine race and income disparities in proximity to pollution is to look for visual correlation patterns by mapping the locations of TRI

\footnotetext{
6 http://www.epa.gov/tri/tridata/index.html.
} 
sites and comparing them with neighborhood demographics. Figure 1 compares EPA geocoded site locations to 2000 Census Block Groups described by the percentage of people of color. Figure 2 compares EPA geocoded site locations to 2000 Census Block Groups described by household income. The visual correlation between race/income and proximity is consistent with other studies that suggest low-income people of color often live close to hazardous sites. Table 1 describes the correlation between 2005-2009 census tract racial percentages and number of TRI facilities within 1 mile of the tract centroid at that time. This correlation is particularly severe for Hispanics. The next step is to determine what forces lead to these patterns - in particular, is there evidence that they were the result of post-siting market dynamics?

\section{HOUSING AND HOMEBUYER DATA}

We use two types of socioeconomic data in this paper: aggregate demographic and economic data measured at the census tract and individual homebuyer repeat-purchase microdata constructed from residential transactions data.

\subsection{Census Tract Data}

We use data provided by the U.S. Census Bureau describing tract-level demographic and economic statistics for two periods: the 2000 Decennial Census and the 2005-2009 American Community Survey 5-year estimates. Each provides a 5\% sample of the total population. Variables include: population by Hispanic or Latino origin and race, median household income, percent of households in poverty, percent of population foreign born, percent of population over 25 who are high school dropouts or college graduates, and median owner-stated house value. 
Table 2 describes the characteristics of 1,872 L.A. County tracts for which we have no missing observations in either year. Notable amongst these figures is a sharp drop in the percentage of high school dropouts, and the fact that Hispanics constitute a plurality in Los Angeles county.

\subsection{Individual Homebuyer Data}

We also use proprietary data on residential real estate transactions and mortgage information from the L.A. County area. In particular, the commercial firm DataQuick Information Systems provides information on real estate transactions between 1998 and 2008. Variables include a unique parcel identifier, transfer value (e.g., actual sale price), sale date, and geographic information (e.g., census tract, latitude, longitude). Other housing characteristics include lot size, square footage, number of bathrooms, and number of bedrooms. Over $70 \%$ of the DataQuick transactions have been matched previously with loan information collected under the Home Mortgage Disclosure Act (HMDA) (Bayer et al. 2011). The match adds homebuyer race/ethnicity and income to each residential transaction record.

Because we are interested in typical single-family residential homes, we eliminate landonly properties, multiunit properties (i.e., condos), and real estate transactions with unusual purchase and repurchase patterns. For example, in our sample, homes that sold more than three times or multiple times within the same year were excluded because high turnover rates and seller name information suggest that they were likely to be investment properties. Because housing characteristics are only available for the last recorded transaction, we screened for properties that were identified by DataQuick as having undergone significant improvements between the first and last sales. Even after applying the screening procedures, we have a sample 
of 527,274 Los Angeles County single-family residential homes sales. Summary statistics for the variables we use are provided in Table 3 .

Because the DataQuick transactions cover all Los Angeles County home sales during the sample period, we are able to follow a person who buys a house, subsequently sells that house, and moves to another house within the county in the sample period. A matching procedure developed by Bayer et al. (2011) does this, using buyer and seller names for a given Los Angeles County home sale, recording the date for each subsequent home sale, and searching all other Los Angeles County home sales for candidate matches that fall within the same time window. If a buyer's name within the set of candidate houses matches the name of the seller of the house in question, the procedure considers it to be a repeat within-county buyer. If not, we assume that the household had either left the county or moved to a rental unit.

Our panel data keeps the housing transactions where we see the same buyer make two purchases within Los Angels County. Even after using the restrictions, the resulting group includes over 25,000 homebuyers. For the purpose of comparison, the only other individuallevel study (Crowder and Downey 2010) uses only 13,000 households, and these are spread across the entire United States. ${ }^{7}$

To assess whether the sample restrictions raise selection issues with respect to race, we compare the Los Angeles County buyer-based panel sample statistics with individuals in 20062010 Census statistics who had moved since 1998 (Table 4). We find that the repeat purchase sample is similar to the Los Angeles Census statistics, with slight oversampling of whites at the

\footnotetext{
${ }^{7}$ By restricting our sample to be composed of movers within a single metropolitan area (L.A. County), we eliminate changes in unobservable MSA-level attributes that could be determinants of the moves considered by Crowder and Downey (2010). Failure to control for these unobservable attributes could distort estimates of the relative tradeoffs made by individuals in different race groups.
} 
expense of Hispanics. Table 5 provides more detailed statistics summarizing the observable attributes of the current home and the previous home each individual owned.

As shown in Figure 3, only 5\% of the white homebuyers started and stayed within one mile of the TRI site. An additional $11 \%$ of the white homebuyers came to the nuisance; that is, they decided to move from outside to inside one mile. In contrast, people of color were more likely than whites to both start and stay near and come to the nuisance. Asian homebuyer patterns were 10\% (start and stay) and 18\% (come to the nuisance), black homebuyers patterns were $17 \%$ (start and stay) and 16\% (come to the nuisance), and Hispanic home buying patterns were $16 \%$ (start and stay) and 19\% (come to the nuisance). These figures suggest that the market dynamics hypothesis may be able to explain at least part of the observed correlation between race and pollution, but they do not say anything about the role of other factors that might be correlated with pollution exposure. For this reason, the EJ literature has focused on multivariate regression to look for evidence of market dynamics.

\subsection{Property Crime}

The property crime rate that we employ comes from the RAND California database and is defined as the number of incidents per 100,000 residents in a "city" located within the Los Angeles metropolitan area. The data describe property and violent crime rates for 175 cities in the Los Angeles metropolitan area between 1986 and 2008. Property crime is defined as "crimes against property, including burglary and motor vehicle theft." Currently, we calculate crime rates for a census tract using the average of the 3 cities nearest the census tract centroid. We calculate crime rates each house in our data set using the nearest city. 


\subsection{School Quality}

The school quality data (elementary school and high school) comes from the California Department of Education. To measure school quality, we use the Academic Performance Index, a single number that ranges from a low of 200 to a high of 1000 . Currently, we calculate a school quality measure for a census tract using the average of the 3 schools (elementary and high school) nearest the census tract centroid. We also calculate school quality for each house using the nearest school.

\section{TRACT-LEVEL EMPIRICAL ANALYSIS}

\subsection{Traditional Census Tract Analysis}

We begin with a traditional EJ market dynamics model, which examines the statistical relationship between changes in aggregate tract-level demographics and a variety of tract attributes (including TRI exposure). We therefore report the results of the following specification in Table 6.

$$
\begin{aligned}
& \Delta \% R_{j}=\beta_{0}+\beta_{1} X+\beta_{2} \% \text { POVERTY }{ }_{2000, j}+\beta_{3} \% \text { FOREIGN }_{2000, j}+ \\
& \beta_{4} \% \text { FEMALE_HH }{ }_{2000, j}+\beta_{5} \% H S_{-} D R O P_{2000, j}+ \\
& \beta_{6} \% \text { BA_DEGREE }{ }_{2000, j}+\beta_{7} \text { HOUSE_VALUE } E_{2000, j}+ \\
& \beta_{8} \text { PROP_CRIME } E_{2000, j}+\beta_{9} A P I_{-} E L E M_{2000, j}+ \\
& \beta_{10} A P I_{-} H S_{2000, j}+u_{j}
\end{aligned}
$$


where $X=T R I_{2000, j}$ (left panel) or $\Delta T R I_{j}$ (right panel), and $\Delta \% R_{j}$ measures the change in the percentage of race group $R$ in tract $j .{ }^{8}$ Consistent with much of the literature, we fail to find any evidence of significant correlations between racial dynamics and pollution exposure.

\subsection{A Structural Model of Neighborhood Dynamics}

The model in this section builds upon the framework used in Section 2 to illustrate why a simple analysis of demographic changes at the tract level is unable to identify post-siting market dynamics. In particular, by imposing some structure on $s_{j, k}$ (the share of individuals of a particular group in tract $k$ who choose to move to tract $j$ ), we are able to identify the role of TRI exposure in driving those moves. Equations (1) and (2) represented a system of six equations with nine unknown $s_{j, k}$ 's, leading to an identification problem. By instead parameterizing $s_{j, k}$ as a function of location attributes, this identification problem can be overcome.

Building upon the simple example described in Section 2, we begin with the predicted population in neighborhood $j$ in period $\mathrm{B}$ :

$$
\operatorname{pop}_{j}^{B}=\sum_{k=1}^{N} s_{j, k} \text { pop }_{k}^{A}
$$

\footnotetext{
${ }^{8}$ Because of concerns over causality, we do not include a specification that controls for changes in sociodemographic variables or median house value, as the 2007 values of these variables are likely to be determined by the population dynamics that we seek to model.
} 
We specify the mean utility from living in location $k\left(\delta_{k}\right)$ as a function of observable attributes of that location $\left(X_{k}\right)$, attributes that are unobserved by the econometrician $\left(\xi_{k}\right)$, and a vector of parameters $(\beta)$ :

$$
\delta_{k}=f\left(X_{k}, \xi_{k} ; \beta\right)
$$

We return to the relationship between $\delta_{k}, X_{k}$, and $\xi_{k}$ below. For now, we simply specify that the utility an individual $i$ receives from living in location $k$ is given by:

$$
U_{i, k}=\delta_{k}+\eta_{i, k}
$$

where $\eta_{i, k}$ refers to the idiosyncratic utility that individual $i$ receives from living in location $k$. The change in utility an individual $i$ currently living in location $k$ receives from moving to location $j$ is therefore given by:

$$
U_{i, j}-U_{i, k}=\left(\delta_{j}-\delta_{k}\right)-\mu D I S T_{j, k}+\left(\eta_{i, j}-\eta_{i, k}\right)
$$

where $D I S T_{j, k}$ is the distance in kilometers between the centroids of tract $j$ and $k . \mu$ measures the disutility of moving. The change in utility from staying in one's current location is zero. 
If $\eta_{i, k}$ is distributed i.i.d. Type I extreme value, then the share of individuals in location $k$ who find it optimal to move to location $j$ is given by the familiar logit functional form:

$$
s_{j, k}=\frac{e^{\left(\delta_{j}-\delta_{k}-\mu D I S T_{j, k}\right)}}{\sum_{l=1}^{N} e^{\left(\delta_{l}-\delta_{k}-\mu D I S T_{l, k}\right)}}
$$

Similarly, the share of individuals in location $k$ who would find it optimal to remain in that location is given by:

$$
s_{k, k}=\frac{1}{\sum_{l=1}^{N} e^{\left(\delta_{l}-\delta_{k}-\mu D I S T_{l, k}\right)}}
$$

\subsubsection{Open Migration Systems}

The model of migration becomes even more complicated when we recognize that many of the observed changes in the distribution of population may actually reflect broader migration patterns into and out of the "system" being considered. The problem of the "open system" is commonplace amongst papers looking for evidence of post-siting market dynamics. It arises whenever the researcher considers a subset of locations, allowing movements into and out of that subset. Been (1994), for example, considers only those census tracts surrounding the nuisances used by GAO (1983) and Bullard (1983). Oakes, Anderton, and Anderson (1996) use only tracts containing TSDF's and a small subset of control tracts. Been and Gupta (1997) use 544 communities that hosted active TSDF's in 1994, and Morello-Frosch et al. (2002) use census 
tracts in the South Coast Air Quality Management District. In analyses of the Superfund program, Greenstone and Gallagher (2008) use a set of census tracts in buffers surrounding the set of several hundred sites that were assigned HRS scores by EPA in 1982; Gamper-Rabindran and Timmins (2011) use a similarly defined set of census blocks.

In the estimation below, we consider movements within L.A. County census tracts $(k=1$, $2, \ldots, N)$ and a single "catch-all" location $(k=\mathrm{N}+1)$ that captures all other locations. This simplification and, in particular, the number of individuals assumed to be in the catch-all location, is innocuous when it comes to identification and estimation.

\subsubsection{Timeperiods}

We use data from the 2000 decennial census to define period A, and data from the 20052009 5-year American Community Survey sample to define period B. Both data sets take 5\% samples of the total population. For the sake of simplicity, we will refer to the two periods as 2000 and 2007.

\subsubsection{Estimation}

Estimation is carried out in two stages and is based on the procedure described in Timmins and Murdock (2007). In particular, we begin by finding the vector of $\left\{\delta_{k}\right\}_{k=1}^{N+1}$ and $\mu$ that best fit the data. Of course, without additional information, this system contains $\mathrm{N}+2$ unknowns and only $\mathrm{N}+1$ equations describing the mapping of populations from 2000 to 2007 in each location. It is therefore still unidentified. We do have access, however, to an additional piece of information that solves this problem. In particular, we observe the share of households in each race subgroup in L.A. county that do not move between 2000 and 2007 ( $\%$ Stay $_{\text {white }}=$ 
$42.51 \%, \%$ Stay $_{\text {black }}=36.23 \%, \%$ Stay ${ }_{\text {Asian }}=32.78 \%, \%$ Stay $\left.{ }_{\text {Hispanic }}=32.63 \%\right) .{ }^{9}$ This provides us with an additional equation that must hold for each race group $R$ :

$$
\frac{\sum_{k=1}^{N} s_{k, k} \operatorname{pop}_{k}^{2000, R}}{\sum_{k=1}^{N} \operatorname{pop}_{k}^{2007, R}}=\% \text { Stay }_{R}
$$

Practically, solving for $\left\{\delta_{k}\right\}_{k=1}^{N+1}$ and $\mu$ is made simple by noting that, if we divide both sides of

equation (4) by TOTPOP $=\sum_{k=1}^{N+1} p o p_{k}^{2000}=\sum_{k=1}^{N+1} p o p_{k}^{2007}$, we get:

$$
\sigma_{j}^{2007}=\sum_{k=1}^{N+1}\left(\frac{e^{\left(\delta_{j}-\delta_{k}-\mu D I S T_{j, k}\right)}}{\sum_{l=1}^{N+1} e^{\left(\delta_{l}-\delta_{k}-\mu D I S T_{l, k}\right)}}\right) \sigma_{k}^{2000} \quad j=1,2, \ldots, N+1
$$

where $\sigma_{j}^{t}=\frac{p o p_{j}^{t}}{\text { TOTPOP }^{\prime}} .10$ Conveniently, given a guess at $\mu$, equation (11) represents a contraction

mapping in $\left\{\delta_{k}\right\}_{k=1}^{N+1}$. We can solve for those values by first taking a guess $\left(\bar{\delta}^{0}\right)$ subject to a

\footnotetext{
${ }^{9}$ Specifically, the 2007 3-year ACS describes the year in which each household moved into its current residence. We find the percentage of households who moved into their current house in or before 2000. Note that, in our model, not moving corresponds simply to remaining in the same census tract, while in our data, not moving corresponds to remaining in the same house. We do not expect within-tract moves to be common, meaning that this difference should not have a significant effect on our results. Using our DataQuick sample, we find that only $7 \%$ of all moves are within-tract.

${ }^{10}$ Note that, by introducing the "catch-all" location $k=\mathrm{N}+1$, we can effectively make this into a closed system, where anyone entering L.A. County comes from location $\mathrm{N}+1$ and anyone leaving it moves to location $\mathrm{N}+1$. Of course, the size of the mean utility we impute to the catch-all location will be determined by the number of people
} 
suitable normalization. ${ }^{11}$ We then use that guess in conjunction with the observed population shares in $2000\left(\bar{\sigma}^{2000}\right)$ to calculate predicted population shares in $2007\left(\tilde{\sigma}_{j}^{2007,0}\right) \forall j$. We then update the $\bar{\delta}$ guess according to the following rule, which parallels that used in Berry (1994):

$$
\delta_{j}^{1}=\delta_{j}^{0}+\left(\ln \sigma_{j}^{2007}-\ln \tilde{\sigma}_{j}^{2007,0}\right)
$$

The vector $\bar{\delta}^{1}$ is used to generate predictions of $\tilde{\sigma}_{j}^{2007,1} \forall j$, which in turn are used to generate a new vector $\bar{\delta}^{2}$. This process is repeated until the difference between $\left|\delta_{j}^{m+1}-\delta_{j}^{m}\right|<\varepsilon \forall j$ $\left(\varepsilon=10^{-8}\right)$. Estimates of $\delta_{j}$ are then used in a regression based on equation (5). Given those values and the guess at $\mu$, we then calculate the predicted percentage of the 2007 population who did not move from their tract in 2000 , and check to see how that value compares with $\%$ Stay $_{R}$ for the appropriate racial group. We use a bisection method to search over values of $\mu$ that equate predicted $\% \operatorname{Stay}_{R}$ to actual $\%$ Stay ${ }_{R}$, solving for the values of $\left\{\delta_{k}\right\}_{k=1}^{N+1}$ at each step.

we assume to be there. This does not present a problem as long as we do not attempt to interpret the mean utility of location $\mathrm{N}+1$. What is important is that the values of the mean utilities associated with the other locations $(k=1$, $2, \ldots, N$ ) are not affected by the assumed population of $\mathrm{N}+1$. We find this to indeed be the case, with our results being essentially identical regardless of whether we define the population of $\mathrm{N}+1$ to be 2,4 , or 6 times the net change in population in $(k=1,2, \ldots, N)$ between 2000 and 2007.

${ }^{11}$ In general, there is no scale associated with the vector of utility indices (i.e., one could add an arbitrary constant value to all of them and not impact the behavioral shares). As such, a normalization is required. We normalize the values such that they are mean zero. 


\subsubsection{Complication: Zero Shares}

The methodology described above assumes a positive population share $\left(\sigma_{j}\right)$ in each location in each period. In our EJ application, we apply this procedure to different racial groups. Using a high-resolution definition of geography (e.g., census tracts), it is possible to observe tracts containing no members of a particular group. This is, in fact, the case in L.A. County, where $3.4 \%$ of tracts contain no whites, $14.9 \%$ contain no blacks, $10.2 \%$ contain no Asians, and $0.2 \%$ contain no Hispanics. This creates a practical difficulty, as equation (12) is not defined for a particular value of $j$ if $\sigma_{j}^{2007}=0$.

We deal with this problem by following a strategy similar to that used by Timmins and Murdock (2007). They show that, by adding a "patch" - i.e., a small positive artificial population $\rho$ (e.g., $\rho=10^{-3}$ ) to each location, all locations will have positive shares and the procedure described above will be computationally feasible. Moreover, the value of $\delta_{j}$ associated with zero-share locations will become increasingly negative as the value of $\rho$ becomes smaller and smaller $\left(\delta_{j} \rightarrow-\infty\right.$ as $\left.\rho \rightarrow 0\right)$. This would create a problem using a leastsquares regression technique to decompose $\left\{\delta_{k}\right\}_{k=1}^{N}{ }^{12}$ Consider a linear specification of equation (5):

$$
\delta_{k}=X_{k}^{\prime} \beta+\xi_{k}
$$

\footnotetext{
12 Note that we do not have $X_{j}$ data for the "catch-all" location $\mathrm{N}+1$, and the value of $\delta_{k}, k=\mathrm{N}+1$ depends upon the assumed population of that location. We therefore drop location $\mathrm{N}+1$ from the second stage of the estimation procedure.
} 
In particular, estimates of $\beta$ will vary with the choice of $\rho$. However, if fewer than half of all locations have positive population shares, we can decompose $\left\{\delta_{k}\right\}_{k=1}^{N}$ into its component parts using median regression. Median regression is a particular case of quantile regression (Koenker 2005 ) that is robust to the choice of $\rho$. Figure 4 illustrates this point. In particular, it shows three different distributions of $\delta_{j}$ corresponding to patches of $\rho=10^{-3}, 10^{-6}$, and $10^{-9}$. In each case, the distribution is bi-modal. An upper portion represents the distribution of $\delta_{j}$ that corresponds to locations with positive shares; this portion of the distribution is practically invariant to the choice of $\rho$. The lower portion of the distribution contains estimates of $\delta_{j}$ associated with zero-share locations. This part of the distribution moves further to the left as the value of $\rho$ gets smaller. This would have an impact on least squares regression estimates; however, with fewer than half of the $\delta_{j}{ }^{\prime} s$ falling in this lower part of the distribution, median regression results are essentially invariant to the choice of $\rho$. Table A1 in the Appendix reports least-squares and median regression results showing this explicitly for $\rho=10^{-3}, 10^{-6}$, and $10^{-9}$.

We use either 2000 sociodemographics or an average of 2000 and 2007 sociodemographics to model the determinants of movements between 2000 and 2007. The idea is that residents will decide to move at some point between those two years based on the attributes they see, and the new 2007 values of variables like \% Poverty and \% Bachelors Degree will be determined by that sorting process. Using the 2000 values is a more conservative approach that avoids problems of reverse causality; it is also the approach typically adopted in the EJ literature. We show, however, that results are robust to using 2000-2007 average attributes. It is still possible, however, that tract attributes could be correlated with tract-level 
unobservables. While we do not currently use any instruments for tract attributes that are correlated with tract unobservables, doing so would be a simple extension of the quantile regression framework to the IV quantile method proposed by Hansen and Chernozhukov (2005).

\subsection{Applying Structural Model to Stylized Examples}

In this sub-section, we apply the structural model described above to the three examples used in Section 2 to illustrate that the traditional EJ model does not identify housing market dynamics. It is a simple matter to show that the structural model is able to identify those dynamics. Figures $5(\mathrm{a})$ - (c) illustrates the mean utilities $\left(\delta_{j}\right)$ recovered from a contraction mapping applied to the three locations versus the level of the nuisance in each. A simple linear fit applied to those points shows that the structural model is indeed able to recover "coming to the nuisance" behavior in Examples \#1 and \#3, and "fleeing the nuisance" behavior in Example $\# 2$.

\subsection{Structural Model Results}

The first stage of our structural estimation procedure recovers values for $\mu$ that make predicted "stay" percentages exactly equal to observed "stay" percentages for each race group. These estimates are: $\mu_{\text {Asian }}=1.16216, \mu_{\text {Black }}=1.36284, \mu_{\text {Hisp }}=1.30202$, and $\mu_{\text {White }}=1.20122$.

Results of the quantile second-stage regressions are described in Table $7 .{ }^{13}$ Using either $T R I_{2000}$ or $A V G T R I$ to measure the nuisance, whites, Asians and blacks all exhibit statistically significant "fleeing" behavior, although the fleeing effect for whites is significantly larger than

\footnotetext{
13 Table A2 in the appendix reports results using the natural log of moving distance in the first stage.
} 
that of the other two minority groups. Hispanics actually exhibit a statistically significant "coming to the nuisance" behavior. Together, these estimates explain the correlations described in Table 1; if these behaviors were allowed to play-out over time, we would expect to see a large negative correlation with TRI exposure for whites, a large positive correlation for Hispanics, and black and Asian correlation falling somewhere in between.

Mean TRI exposure in 2000 is equal to $0.944(\approx 1)$. At that mean, these coefficient estimates can be readily interpreted as the elasticity of the share of each race group who choose to remain in a particular neighborhood with respect to a change in that neighborhood's TRI

exposure $\left(e_{T R I}^{s_{j, j}}=\frac{\partial s_{j, j} T R I_{j}}{\partial T R I} s_{j, j}=\beta_{T R I} T R I_{j}\right)$. A $1 \%$ increase in TRI exposure therefore reduces the share of whites, Asians, and blacks choosing to remain in a tract by $0.26 \%, 0.11 \%$, and $0.15 \%$, respectively. It increases the share of Hispanics choosing to remain there by $0.03 \%$.

\section{INDIVIDUAL HOMEBUYER ANALYSIS}

Next, we look at the residential moves made by individual members of each racial group and the tradeoffs in other house and neighborhood attributes that accompany those moves. There are three key differences between individual data and the aggregate data used in the previous section. First, with individual data, we are able to control for "starting" and "ending" circumstances that accompany a move. Specifically, we use information on the starting and ending proximity to a TRI facility, housing services and numerous dimensions of neighborhood quality associated with each move. A second difference is that, unlike tract-level data, with individual data we know the precise point in time when each individual moves. Whereas we used the 2000 or the $2000-2007$ average TRI exposures in that analysis, we are able to use the 
exact change in TRI exposure that accompanies the move in the year when that move takes place for the analysis described below. Third, with individual data, we can control for both race and income as determinants of moving behavior; cross-tab data on race and income are not available at a sufficient level of geographic resolution to include income as a control in the tract-level analysis.

\subsection{Moving Patterns}

Our analysis of moving patterns starts by looking at the choices made by homebuyers who initially reside inside a one-mile radius drawn around one of the Los Angeles TRI sites. During their subsequent move, we determine whether certain racial groups are more or less likely to move outside of that 1 mile radius (i.e. flee the nuisance). A binary outcome model for the probability of leaving $(p)$ is used, where the dependent variable $(y)$ takes one of two values:

$$
y=\left\{\begin{array}{ccc}
1 & \text { move outside } 1 \text { mile buffer } & p \\
0 & \text { remain inside } 1 \text { mile buffer } & 1-p
\end{array}\right.
$$

The probit model is specified where $p$ depends race groups and income $(x)$ and $F$ is the standard normal cumulative distribution function.

$$
p \equiv \operatorname{Pr}(y=1 \mid x)=F\left(x^{\prime} \theta\right)
$$

As shown in the left column of Table 8, white buyers (i.e., the excluded group) starting close to TRI sites are more likely to leave the nuisance relative to people of color, and the 
likelihood of fleeing increases with income. Individual results parallel the results of our structural model. Of the four race groups, Hispanics are the least likely to move out of the TRI buffer.

Having found evidence of differential "fleeing" across the race groups, we now look to see whether there is additional evidence in micro data that certain groups actually come to the nuisance. To address the question, we use choices for buyers who initially started outside of the one-mile radius around a TRI site. During subsequent moves, we determine whether each racial group is more or less likely to locate inside a one-mile radius (i.e. come to the nuisance). We use a similar binary outcome model approach where the dependent variable $(y)$ takes one of two values:

$$
y=\left\{\begin{array}{llc}
1 & \text { move inside } 1 \text { mile buffer } & p \\
0 & \text { remain outside } 1 \text { mile buffer } & 1-p
\end{array}\right.
$$

The second probit model results, described in the right column of Table 8 , show that there are economically significant differences in the probability of coming to the nuisance between whites and all other racial groups. Although no group is likely to come to the nuisance, all minority groups are significantly more likely than whites to move closer to TRI facilities; the difference between whites and Hispanics is most economically significant. As a result, we find direct evidence of different sorting responses that may lead to long-run racial differences in TRI exposure. 


\subsection{Tradeoffs}

One of the most important concepts in microeconomics is the budget constraint. Because of it, getting more of something good typically means giving up something else that we like. In order to explore the tradeoffs made by members of different racial groups as they move closer to or further from TRI sites, we consider the changes in living space and some indicators of neighborhood quality that accompany those moves. Specifically, we examine the change in square footage, property crime rate, API score in elementary and high schools, and the change in overall housing expenditure. We do this separately by race and for those who (i) stay inside a one-mile buffer when moving, (ii) move out from inside a one-mile buffer, (iii) remain outside a one-mile buffer, or (iv) move in from outside a one-mile buffer. Results are reported in Table 9. The columns labeled "Diff" report the change in the attribute (i) for those who moved outside the buffer relative to those who stayed inside, and (ii) for those who moved inside the buffer relative to those who stayed outside. The idea is to use the change in the attribute for those who stay (either inside or outside the buffer) as a control for those who move (either outside or into the buffer).

We find that whites moving out of a TRI buffer tend to buy larger houses with less crime and better quality education than do whites moving to another house that is within a 1 mile buffer, but they also pay more. Conversely, whites moving into a buffer experience a worsening of each of these attributes relative to whites who move to another house that is outside a buffer, but they also pay less. Hispanics make a qualitatively similar set of tradeoffs, although the magnitudes of the tradeoffs associated with crime and elementary education are larger. Both of these groups appear to be sacrificing more "other consumption" (i.e., by paying more for a 
house) to get more housing stock and/or better neighborhood amenities, including less exposure to TRI pollution (or vice-versa).

On average, blacks exhibit a different pattern of tradeoffs. In particular, those moving out of a buffer get a slightly larger house for which they pay more, but also get lower-quality schools. In exchange for a reduction in exposure to pollution, they experience a relative increase in exposure to property crime. In summary, these individuals trade-off school quality and exposure to crime for a reduction in pollution exposure. Blacks starting outside of a buffer engage in a different tradeoff. Those individuals who move into a buffer pay more for a smaller house with more crime and lower quality schools, relative to an individual who moves to another house outside the buffer. This is difficult to explain without introducing some other factor that drives moving decisions. Exploring what these other factors could be is something that we continue to examine.

Finally, Asians moving outside the buffer generally face a smaller increase in price than those remaining inside the buffer. This is in spite of the fact that they get a bigger house and improved school quality. They do, however, also face an increase in property crime. These individuals trade off increased crime for an increase in other consumption, an improvement in school quality, and less exposure to pollution. Asians moving into the buffer, on the other hand, receive worse schools, a smaller house, and higher crime rates relative to those who remain outside the buffer. However, they pay significantly less for their house. In this sense, their tradeoffs are similar to Hispanics and whites. 


\section{CONCLUSIONS}

This study uses two alternative modeling strategies to take a fresh look at an important environmental justice question - what forces lead to the observed correlations between pollution exposure and race and what tradeoffs do different racial groups make between pollution exposure, housing size, and neighborhood quality? Our first approach uses data common in the EJ literature - tract-level aggregate information observed at several points in time. We demonstrate that the typical approach to analyzing these data is not able to identify market dynamics in response to exposure to a nuisance (i.e., "fleeing from" or "coming to"). We do show, however, that with additional modeling structure, these behaviors can be recovered from aggregate data. In an application to TRI exposure in L.A. County, we find evidence of strong "fleeing" behavior on the part of whites (and, to a lesser extent, Asians and blacks) - behavior that, over the long-run, can explain the disproportionate exposure of minority groups (particularly Hispanics) to toxics found in simple correlations. These patterns are not evident based on a simple analysis of the sort typically conducted in the EJ literature.

With access to a unique data source that allows us to track individual home-buyers as they move from one house to another in L.A. County, we are able to demonstrate explicitly that these are indeed the underlying market dynamics with respect to TRI exposure. With these individual-level micro data, we separate out the effects of "coming to" and "fleeing" the nuisance and find evidence of both. Repeated housing choices made by different racial groups provide direct evidence that people of color (particularly Hispanics and poorer residents of all races) are less likely to flee the nuisance while whites are significantly less likely than all three minority groups to come to the nuisance. This simple analysis confirms the results of our structural tract-level analysis, particularly with respect to whites and Hispanics. 
Looking specifically at the tradeoffs that underlie the movements described by our individual micro data, we find that people of all race groups in L.A. County exchange proximity to TRI plants for some combination of school quality, exposure to property crime, house size, and other consumption. This result suggests that the previous reservations expressed about residential sorting stories may be misplaced, especially if stakeholders only interpret them to imply that people of color do not care about environmental quality. Rather, moves involve tradeoffs and minorities may be willing to sacrifice poor environmental quality for improvements in other neighborhood features like school quality, which improve their welfare. Early social advocates, such as Robert Bullard (2000), may have therefore framed residential sorting in an alternative and useful way by conceding that people vote with their feet, but emphasizing differences in opportunities when they exercise their "vote." Our study accepts Bullard's premise and recent suggestions in Banzhaf (2011) that questions related to fairness and injustice may be better addressed by understanding the reasons why different racial groups have different opportunities (e.g. forces determining the underlying distribution of economic resources).

In conclusion, residential sorting behavior presents some unique challenges for environmental justice policy because sorting behavior can undercut well-intentioned policies designed to improve the distribution of environmental quality (Banzhaf 2011). It may also mean that the set of policy levers available are different from those traditionally considered by environmental justice policy makers. For example, if coming to the nuisance is in part driven by deteriorating neighborhood amenities (increases in crime, low performing schools) in environmentally friendly neighborhoods, then policies that improve the quality of public goods in these neighborhoods could indirectly reduce exposure disparities. Policy makers and stakeholders might consider how other policies targeted at non-environmentally related 
neighborhood quality improvements can improve the distribution of environmental quality across different racial group.

\section{REFERENCES}

Banzaf, H.S. 2011. "The political economy of environmental justice: An introduction.” In H.S. Banzaf, ed. The Political Economy of Environmental Justice. Forthcoming. Stanford University Press, Palo Alto, CA. http://www2.gsu.edu/ prchsb/Banzhaf_EJ.html

Banzhaf, H.S. and E. McCormick. 2007. "Moving Beyond Cleanup: Identifying the Crucibles of Environmental Gentrification.” NCEE Working Paper \#07-02.

Banzhaf, H.S. and R.P. Walsh. 2008. "Do people vote with their feet? An empirical test of Tiebout's mechanism." American Economic Review. 98: 843-63.

Banzhaf, H.S. and R.P. Walsh. 2010. "Segregation and Tiebout Sorting: Investigating the Link between Investments in Public Goods and Neighborhood Tipping." NBER Working Paper No. 16057, National Bureau of Economic Research, Inc.

Bayer, P., R. McMillan, A. Murphy, and C. Timmins. 2011. "A dynamic model of demand for houses and neighborhoods." NBER Working Paper No. 17250, National Bureau of Economic Research, Inc.

Been, V. 1994. "Locally Undesirable Land Uses in Minority Neighborhoods: Disproportionate Siting or Market Dynamics." Yale Law Journal. 103:1383-1422.

Been, V. and F. Gupta. 1997. "Coming to the nuisance or going to the barrios? A longitudinal analysis of environmental justice claims." Ecology Law Quarterly 24:1-56.

Berry, S. 1994. "Estimating Discrete-Choice Models of Product Differentiation." RAND Journal of Economics. 25(2):242-262.

Bullard, R.D. 1983. "Solid Waste Sites and the Black Houston Community." Sociological Inquiry. Vol.53(2-3):273-288.

Bullard, R.D. 2000. Dumping in Dixie: Race, Class, and Environmental Quality. 3rd ed. Boulder, CO: West View Press. 
Cameron, T.A., and I.T. McConnaha. 2006. "Evidence of Environmental Migration." Land Economics. 82(2):273-290.

Crowder, K., and L. Downey. 2010. "Interneighborhood Migration, Race, and Environmental Hazards: Modeling Microlevel Processes of Environmental Inequality." American Journal of Sociology. 115(4):1110-49.

de Marchi, S., and J. T. Hamilton. "Assessing the Accuracy of Self-Reported Data: An Evaluation of the Toxics Release Inventory." Journal of Risk and Uncertainty 32, no. 1 (2006): 57-76.

Epple, D., R. Filimon, and T. Romer (1984). "Equilibrium Among Local Jurisdictions: Toward an Integrated Treatment of Voting and Residential Choice." Journal of Public Economics. 24:281-308.

Gamper-Rabindran, S. and C. Timmins. 2011. "Hazardous Waste Cleanup, Neighborhood Gentrification, and Environmental Justice: Evidence from Restricted Access Census Block Data." American Economic Review: Papers and Proceedings. 101(3):620-24.

Greenstone, M. and J. Gallagher. 2008. "Does Hazardous Waste Matter? Evidence from the Housing Market and the Superfund Program." The Quarterly Journal of Economics. 123(3): 951-1003.

Hansen, C. and V. Chernozhukov. 2005. "An Instrumental Variable Model of Quantile Treatment Effects." Econometrica. 73(1), 245-261.

Koehler, Dinah A., and John D. Spengler. "The Toxic Release Inventory: Fact or Fiction? A Case Study of the Primary Aluminum Industry." Journal of Environmental Management 85, no. 2 (2007): 296-307.

Koenker, Roger (2005) Quantile Regression, Cambridge University Press. ISBN 0-521-60827-9

Kuminoff, N., V.K. Smith, and C. Timmins. 2010. "The New Economics of Equilibrium Sorting and Its Transformational Role for Policy Evaluation.” NBER Working Paper \#16349.

Morello-Frosch, R, M. Pastor, C. Porras, and J. Sadd. 2002. "Environmental justice and regional inequality in Southern California: Implications for future research." Environmental Health Perspectives. 110(Supplement 2):149-54.

Natan, T. E., and C. G. Miller. "Are Toxics Release Inventory Reductions Real?" Environmental Science \& Technology 32, no. 15 (1998): 368A-374A.

Oakes, J.M., D.L. Anderton, and A.B. Anderson. 1996. "A Longitudinal Analysis of Environmental Equity in Communities with Hazardous Waste Facilities." Social Science Research. 25:125-48. 
Pastor, M., J. Sadd, and J. Hipp. 2001. "Which Came First? Toxic Facilities, Minority Move-in, and Environmental Justice." Journal of Urban Affairs. 23(1):1-21.

Ruggles, Stephen, Trent Alexander, Katie Genadek, Ronald Goeken, Matthew B. Schroeder, and Matthew Sobek. Integrated Public Use Microdata Series: Version 5.0 [Machine-readable database]. Minneapolis: University of Minnesota, 2010.

Shaikh, S.L. and J.B. Loomis. 1999. "An Investigation Into the Presence and Causes of Environmental Inequity in Denver, Colorado.” Social Science Journal. 36(1):77-92.

Timmins, C. and J. Murdock. 2007. "A Revealed Preference Approach to the Measurement of Congestion in Travel Cost Models." Journal of Environmental Economics and Management. Vol.53(2):230-249.

United Church of Christ. 2007. Toxic Wastes and Race at Twenty: 1987-2007. http://www.ucc.org/assets/pdfs/toxic20.pdf.

US Bureau of the Census. 2011a. American Housing Survey National Tables: 2009. Table 3-11. http://www.census.gov/hhes/www/housing/ahs/ahs09/ahs09.html

US Bureau of the Census. 2011b. The 2011 Statistical Abstract. Table 31.

http://www.census.gov/prod/2011pubs/11statab/pop.pdf

US General Accounting Office (GAO). 1983. Siting of Hazardous Waste Landfills and Their Correlation with Racial and Economic Status of Surrounding Communities. Washington, D.C.: GAO. 
Table 1. Correlation Between Race and TRI Exposure (2005-2009 ACS)

\begin{tabular}{lc}
\hline \hline Asian & -0.1287 \\
Black & 0.0094 \\
Hispanic & 0.3540 \\
White & -0.3003 \\
\hline \hline
\end{tabular}

Table 2. Summary Statistics: Los Angeles County Tract-Level Data

\begin{tabular}{lcc}
\hline \hline \multirow{2}{*}{ Variable } & Census & American Community Survey \\
\hline \% Poverty & 2000 & $2005-2009$ \\
\% Foreign Born & 0.164 & 0.142 \\
& $(0.113)$ & $(0.105)$ \\
\% Female HH & 0.346 & 0.344 \\
& $(0.155)$ & $(0.146)$ \\
\% HS Dropouts & 0.295 & 0.305 \\
& $(0.080)$ & $(0.092)$ \\
\% BA Degree & 0.102 & 0.057 \\
& $(0.102)$ & $(0.085)$ \\
\% Asian & 0.239 & 0.277 \\
& $(0.187)$ & $(0.201)$ \\
\% Black & 0.119 & 0.131 \\
& $(0.141)$ & $(0.157)$ \\
\% Hispanic & 0.091 & 0.081 \\
& $(0.155)$ & $(0.142)$ \\
\% White & 0.424 & 0.455 \\
& $(0.292)$ & $(0.300)$ \\
\hline \hline
\end{tabular}

Note: Variable standard deviations in parentheses. $\mathrm{N}=1,872$. 
Table 3. Los Angeles County Residential Housing Transactions: 1998 to 2008

\begin{tabular}{lcc}
\hline \hline Variable & Available in DataQuick & Sample \\
\hline Price (2000 dollars) & $\$ 350,975$ & $\$ 327,737$ \\
& $(572,270)$ & $(192,337)$ \\
Lot size (acres) & 0.3 & 0.2 \\
& $(16.3)$ & $(0.2)$ \\
Living space $\left(\mathrm{ft}^{2}\right)$ & 1,626 & 1,575 \\
& $(1,065)$ & $(663)$ \\
Number of bathrooms & 2.2 & 2.1 \\
& $(1.1)$ & $(0.8)$ \\
Number of bedrooms & 3.0 & 2.9 \\
& $(1.2)$ & $(0.9)$ \\
Observations & $1,139,633$ & 527,274 \\
\hline \hline
\end{tabular}

Note: Variable standard deviations in parentheses

Table 4. Los Angeles County Homeowners

\begin{tabular}{lcc}
\hline \hline & & 2006-2010, ACS 5-year sample \\
& Residents of L.A. County \\
& $\begin{array}{c}\text { Matched Buyers with Two } \\
\text { Purchases 1998 to 2008 }\end{array}$ & $\begin{array}{c}\text { Occupied Housing Units - } \\
\text { Movers }\end{array}$ \\
\hline Observations & 25,014 & 43 \\
White (percent) & 47 & 17 \\
Asian (percent) & 18 & 33 \\
Hispanic (percent) & 30 & 7 \\
Black (percent) & 6 & 4325 \\
\hline \hline
\end{tabular}

Steven Ruggles, J. Trent Alexander, Katie Genadek, Ronald Goeken, Matthew B. Schroeder, and Matthew Sobek. Integrated Public Use Microdata Series: Version 5.0 [Machine-readable database]. Minneapolis: University of Minnesota, 2010. 
Table 5. Detailed Los Angeles County Individual Repeat Buyer Sample: 1998 to 2008

\begin{tabular}{lcccc}
\hline \hline & Asian & Black & Hispanic & White \\
\hline First Purchase & & & & \\
\hline Price (2000 dollars) & $\$ 329,289$ & $\$ 257,365$ & $\$ 244,980$ & $\$ 354,178$ \\
& $(192,870)$ & $(163,618)$ & $(150,399)$ & $(211,561)$ \\
Lot Size (acres) & 0.2 & 0.1 & 0.2 & 0.2 \\
& $(0.1)$ & $(0.1)$ & $(0.2)$ & $(0.2)$ \\
Living Space (ft $\left.{ }^{2}\right)$ & 0.2 & 0.1 & 0.1 & 0.1 \\
& $(0.2)$ & $(0.2)$ & $(0.2)$ & $(0.2)$ \\
Bathrooms & $1,604.8$ & $1,732.4$ & $1,546.2$ & $1,422.4$ \\
& $(666.5)$ & $(711.2)$ & $(630.1)$ & $(540.3)$ \\
Bedrooms & 2.2 & 2.4 & 2.1 & 2.0 \\
& $(0.8)$ & $(0.8)$ & $(0.8)$ & $(0.8)$ \\
& & & & \\
Second Purchase & & & & \\
& & & & \\
Price (2000 dollars) & $\$ 355,943$ & $\$ 365,186$ & $\$ 300,318$ & $\$ 275,169$ \\
& $(21,561)$ & $(201,890)$ & $(183,032)$ & $(155,564)$ \\
Lot Size (acres) & 0.2 & 0.2 & 0.1 & 0.2 \\
& $(0.2)$ & $(0.2)$ & $(0.2)$ & $(0.2)$ \\
Living Space (ft $\left.{ }^{2}\right)$ & $1,694.9$ & $1,781.2$ & $1,660.1$ & $1,486.2$ \\
& $(717.6)$ & $(751.0)$ & $(698.8)$ & $(570.2)$ \\
Bathrooms & 2.3 & 2.4 & 2.2 & 2.0 \\
& $(0.8)$ & $(0.9)$ & $(0.8)$ & $(0.8)$ \\
Bedrooms & 3.0 & 3.2 & 3.0 & 3.0 \\
& 0.2 & 0.2 & 0.1 & 0.2 \\
Observations & 4,380 & 1,435 & 7,436 & 11,763 \\
\hline \hline
\end{tabular}


Table 6. Traditional Multivariate EJ Test for Market Dynamics

\begin{tabular}{|c|c|c|c|c|c|c|c|c|}
\hline & $\begin{array}{c}\Delta \% \\
\text { Asian }\end{array}$ & $\begin{array}{c}\Delta \% \\
\text { Black }\end{array}$ & $\begin{array}{c}\Delta \% \\
\text { Hispanic }\end{array}$ & $\begin{array}{c}\Delta \% \\
\text { White }\end{array}$ & $\begin{array}{c}\Delta \% \\
\text { Asian }\end{array}$ & $\begin{array}{c}\Delta \% \\
\text { Black }\end{array}$ & $\begin{array}{c}\Delta \% \\
\text { Hispanic }\end{array}$ & $\begin{array}{c}\Delta \% \\
\text { White }\end{array}$ \\
\hline $\mathrm{TRI}_{2000}$ & $\begin{array}{l}-2.41 \mathrm{E}-04 \\
(4.60 \mathrm{E}-04)\end{array}$ & $\begin{array}{c}6.25 \mathrm{E}-04 \\
(3.98 \mathrm{E}-04)\end{array}$ & $\begin{array}{l}-7.89 \mathrm{E}-04 \\
(6.80 \mathrm{E}-04)\end{array}$ & $\begin{array}{c}3.27 \mathrm{E}-04 \\
(6.42 \mathrm{E}-04)\end{array}$ & & & & \\
\hline$\Delta \mathrm{TRI}$ & & & & & $\begin{array}{c}1.53 \mathrm{E}-03 \\
(1.18 \mathrm{E}-03)\end{array}$ & $\begin{array}{l}-1.65 \mathrm{E}-03 \\
(1.02 \mathrm{E}-03)\end{array}$ & $\begin{array}{c}1.81 \mathrm{E}-03 \\
(1.74 \mathrm{E}-03)\end{array}$ & $\begin{array}{l}-1.21 \mathrm{E}-03 \\
(1.64 \mathrm{E}-03)\end{array}$ \\
\hline$\%$ Poverty $_{2000}$ & $\begin{array}{c}-0.0277^{*} \\
(0.015)\end{array}$ & $\begin{array}{c}-0.0337^{* * *} \\
(0.013)\end{array}$ & $\begin{array}{l}0.0203 \\
(0.022)\end{array}$ & $\begin{array}{l}0.0202 \\
(0.021)\end{array}$ & $\begin{array}{c}-0.0273^{*} \\
(0.015)\end{array}$ & $\begin{array}{c}-0.0349^{* * *} \\
(0.013)\end{array}$ & $\begin{array}{l}0.0218 \\
(0.022)\end{array}$ & $\begin{array}{l}0.0196 \\
(0.021)\end{array}$ \\
\hline$\%$ Foreign Born 2000 & $\begin{array}{c}0.0493^{* * *} \\
(7.75 \mathrm{E}-03)\end{array}$ & $\begin{array}{c}0.0312^{* * *} \\
(6.71 \mathrm{E}-03)\end{array}$ & $\begin{array}{c}-0.1801^{* * *} \\
(0.011)\end{array}$ & $\begin{array}{c}0.1462^{* * *} \\
(0.011)\end{array}$ & $\begin{array}{c}0.0494^{* * *} \\
(7.74 \mathrm{E}-03)\end{array}$ & $\begin{array}{c}0.0314^{* * *} \\
(6.70 \mathrm{E}-03)\end{array}$ & $\begin{array}{c}-0.1804^{* * *} \\
(0.011)\end{array}$ & $\begin{array}{c}0.1462^{* * *} \\
(0.011)\end{array}$ \\
\hline$\%$ Female $\mathrm{HH}_{2000}$ & $\begin{array}{c}0.0560^{* * *} \\
(0.014)\end{array}$ & $\begin{array}{c}-0.0832^{* * *} \\
(0.012)\end{array}$ & $\begin{array}{c}-0.0803^{* * *} \\
(0.021)\end{array}$ & $\begin{array}{c}0.1378^{* * *} \\
(0.020)\end{array}$ & $\begin{array}{c}0.0557^{* * *} \\
(0.014)\end{array}$ & $\begin{array}{c}-0.0835^{* * *} \\
(0.012)\end{array}$ & $\begin{array}{c}-0.0799^{* * *} \\
(0.021)\end{array}$ & $\begin{array}{c}0.1378^{* * *} \\
(0.020)\end{array}$ \\
\hline$\%$ HS Dropout ${ }_{2000}$ & $\begin{array}{c}4.05 \mathrm{E}-03 \\
(0.011)\end{array}$ & $\begin{array}{l}-1.53 \mathrm{E}-03 \\
(9.87 \mathrm{E}-03)\end{array}$ & $\begin{array}{l}-0.0248 \\
(0.017)\end{array}$ & $\begin{array}{l}0.0101 \\
(0.016)\end{array}$ & $\begin{array}{c}4.02 \mathrm{E}-03 \\
(0.011)\end{array}$ & $\begin{array}{l}-1.23 \mathrm{E}-03 \\
(9.87 \mathrm{E}-03)\end{array}$ & $\begin{array}{r}-0.0252 \\
(0.017)\end{array}$ & $\begin{array}{l}0.0102 \\
(0.016)\end{array}$ \\
\hline$\%$ BA Degree 2000 & $\begin{array}{c}3.54 \mathrm{E}-04 \\
(0.011)\end{array}$ & $\begin{array}{c}0.0263^{* * *} \\
(9.94 \mathrm{E}-03)\end{array}$ & $\begin{array}{c}-0.1065^{* * *} \\
(0.017)\end{array}$ & $\begin{array}{c}0.0827^{* * *} \\
(0.016)\end{array}$ & $\begin{array}{c}-3.57 \mathrm{E}-05 \\
(0.011)\end{array}$ & $\begin{array}{c}0.0254^{* * *} \\
(9.86 \mathrm{E}-03)\end{array}$ & $\begin{array}{c}-0.1052^{* * *} \\
(0.017)\end{array}$ & $\begin{array}{c}0.0826^{* * *} \\
(0.016)\end{array}$ \\
\hline Med Housing Value 2000 & $\begin{array}{c}-3.53 \mathrm{E}-08^{* * *} \\
(1.05 \mathrm{E}-08)\end{array}$ & $\begin{array}{l}-1.74 \mathrm{E}-08^{*} \\
(9.10 \mathrm{E}-09)\end{array}$ & $\begin{array}{l}-2.88 \mathrm{E}-08^{*} \\
(1.56 \mathrm{E}-08)\end{array}$ & $\begin{array}{l}7.94 \mathrm{E}-08^{* * *} \\
(1.47 \mathrm{E}-08)\end{array}$ & $\begin{array}{c}-3.51 \mathrm{E}-08^{* * *} \\
(1.05 \mathrm{E}-08)\end{array}$ & $\begin{array}{l}-1.71 \mathrm{E}-08^{*} \\
(9.09 \mathrm{E}-09)\end{array}$ & $\begin{array}{l}-2.93 \mathrm{E}-08^{*} \\
(1.55 \mathrm{E}-08)\end{array}$ & $\begin{array}{l}7.94 \mathrm{E}-08^{* * *} \\
(1.47 \mathrm{E}-08)\end{array}$ \\
\hline Property Crime & $\begin{array}{l}-8.76 \mathrm{E}-08 \\
(1.12 \mathrm{E}-06)\end{array}$ & $\begin{array}{c}4.69 \mathrm{E}-07 \\
(9.68 \mathrm{E}-07)\end{array}$ & $\begin{array}{l}-2.09 \mathrm{E}-06 \\
(1.66 \mathrm{E}-06)\end{array}$ & $\begin{array}{c}1.37 \mathrm{E}-06 \\
(1.56 \mathrm{E}-06)\end{array}$ & $\begin{array}{l}-5.21 \mathrm{E}-08 \\
(1.12 \mathrm{E}-06)\end{array}$ & $\begin{array}{c}4.78 \mathrm{E}-07 \\
(9.68 \mathrm{E}-07)\end{array}$ & $\begin{array}{l}-2.11 \mathrm{E}-06 \\
(1.65 \mathrm{E}-06)\end{array}$ & $\begin{array}{c}1.36 \mathrm{E}-06 \\
(1.56 \mathrm{E}-06)\end{array}$ \\
\hline API Elementary & $\begin{array}{l}6.36 \mathrm{E}-05^{* * *} \\
(1.38 \mathrm{E}-05)\end{array}$ & $\begin{array}{l}2.15 \mathrm{E}-05^{*} \\
(1.20 \mathrm{E}-05)\end{array}$ & $\begin{array}{c}2.36 \mathrm{E}-05 \\
(2.05 \mathrm{E}-05)\end{array}$ & $\begin{array}{c}-1.00 \mathrm{E}-04^{* * *} \\
(1.93 \mathrm{E}-05)\end{array}$ & $\begin{array}{l}6.29 \mathrm{E}-05^{* * *} \\
(1.38 \mathrm{E}-05)\end{array}$ & $\begin{array}{l}2.12 \mathrm{E}-05^{*} \\
(1.20 \mathrm{E}-05)\end{array}$ & $\begin{array}{c}2.43 \mathrm{E}-05 \\
(2.04 \mathrm{E}-05)\end{array}$ & $\begin{array}{c}-1.00 \mathrm{E}-04^{* * * *} \\
(1.93 \mathrm{E}-05)\end{array}$ \\
\hline API High School & $\begin{array}{l}7.62 \mathrm{E}-05^{* * *} \\
(1.49 \mathrm{E}-05)\end{array}$ & $\begin{array}{l}5.03 \mathrm{E}-05^{* * *} \\
(1.29 \mathrm{E}-05)\end{array}$ & $\begin{array}{c}-6.27 \mathrm{E}-05^{* * *} \\
(2.21 \mathrm{E}-05)\end{array}$ & $\begin{array}{c}-6.44 \mathrm{E}-05^{* * *} \\
(2.08 \mathrm{E}-05)\end{array}$ & $\begin{array}{l}7.68 \mathrm{E}-05^{* * *} \\
(1.49 \mathrm{E}-05)\end{array}$ & $\begin{array}{l}4.98 \mathrm{E}-05^{* * *} \\
(1.29 \mathrm{E}-05)\end{array}$ & $\begin{array}{l}-6.23 \mathrm{E}-05^{* * *} \\
(2.21 \mathrm{E}-05)\end{array}$ & $\begin{array}{l}-6.48 \mathrm{E}-05^{* * *} \\
(2.08 \mathrm{E}-05)\end{array}$ \\
\hline Constant & $\begin{array}{c}-0.0925^{* * *} \\
(0.012)\end{array}$ & $\begin{array}{c}-0.0360^{* * *} \\
(0.010)\end{array}$ & $\begin{array}{c}0.1748^{* * *} \\
(0.018)\end{array}$ & $\begin{array}{c}-0.0644^{* * *} \\
(0.017)\end{array}$ & $\begin{array}{c}-0.0924^{* * *} \\
(0.012)\end{array}$ & $\begin{array}{c}-0.0350^{* * *} \\
(0.010)\end{array}$ & $\begin{array}{c}0.1733^{* * *} \\
(0.018)\end{array}$ & $\begin{array}{c}-0.0641^{* * *} \\
(0.017)\end{array}$ \\
\hline $\mathrm{R}^{2}$ & 0.0778 & 0.1435 & 0.1898 & 0.2471 & 0.0785 & 0.1436 & 0.1897 & 0.2472 \\
\hline Observations & 1,872 & 1,872 & 1,872 & 1,872 & 1,872 & 1,872 & 1,872 & 1,872 \\
\hline
\end{tabular}

Indicates significance at $10 \%\left({ }^{*}\right), 5 \%\left(\left(^{* *}\right)\right.$, and $1 \%\left({ }^{* * *}\right)$. Standard errors in parentheses. 
Table 7. Structural Model of Market Dynamics (Median Regression)

\begin{tabular}{|c|c|c|c|c|c|c|c|c|}
\hline Dependent Variable & $\delta_{j}^{\text {Asian }}$ & $\delta_{j}^{\text {Black }}$ & $\delta_{j}^{H i s p}$ & $\delta_{j}^{\text {White }}$ & $\delta_{j}^{\text {Asian }}$ & $\delta_{j}^{\text {Black }}$ & $\delta_{j}^{H i s p}$ & $\delta_{j}^{\text {White }}$ \\
\hline $\mathrm{TRI}_{2000}$ & $\begin{array}{c}-0.1053^{* * *} \\
(0.020)\end{array}$ & $\begin{array}{c}-0.1477^{* * *} \\
(0.056)\end{array}$ & $\begin{array}{l}0.0286^{*} \\
(0.0158)\end{array}$ & $\begin{array}{c}-0.2573^{* * *} \\
(0.058)\end{array}$ & & & & \\
\hline Avg TRI & & & & & $\begin{array}{c}-0.1312^{* * *} \\
(0.023)\end{array}$ & $\begin{array}{c}-0.1683^{* * *} \\
(0.065)\end{array}$ & $\begin{array}{l}0.0383^{* *} \\
(0.018)\end{array}$ & $\begin{array}{c}-0.3124^{* * *} \\
(0.066)\end{array}$ \\
\hline$\%$ Poverty $_{2000}$ & $\begin{array}{c}-5.9857^{* * *} \\
(0.658)\end{array}$ & $\begin{array}{l}2.1428 \\
(1.825)\end{array}$ & $\begin{array}{l}1.2347^{* *} \\
(0.518)\end{array}$ & $\begin{array}{l}-0.0385 \\
(1.885)\end{array}$ & $\begin{array}{c}-6.1690^{* * *} \\
(0.661)\end{array}$ & $\begin{array}{l}2.3194 \\
(1.863)\end{array}$ & $\begin{array}{l}1.1586^{* *} \\
(0.518)\end{array}$ & $\begin{array}{l}-0.1663 \\
(1.911)\end{array}$ \\
\hline$\%$ Foreign Born 2000 & $\begin{array}{c}3.0016^{* * *} \\
(0.339)\end{array}$ & $\begin{array}{c}-4.5146^{* * *} \\
(0.940)\end{array}$ & $\begin{array}{c}-5.3511^{* * *} \\
(0.267)\end{array}$ & $\begin{array}{c}7.8585^{* * *} \\
(0.971)\end{array}$ & $\begin{array}{c}2.9754^{* * *} \\
(0.340)\end{array}$ & $\begin{array}{c}-4.4739^{* * *} \\
(0.959)\end{array}$ & $\begin{array}{c}-5.3577^{* * *} \\
(0.267)\end{array}$ & $\begin{array}{c}7.8717^{* * *} \\
(0.984)\end{array}$ \\
\hline$\%$ Female $\mathrm{HH}_{2000}$ & $\begin{array}{l}1.0324^{*} \\
(0.615)\end{array}$ & $\begin{array}{c}-3.6636^{* *} \\
(1.705)\end{array}$ & $\begin{array}{c}-5.0735^{* * *} \\
(0.484)\end{array}$ & $\begin{array}{c}18.325^{* * *} \\
(1.761)\end{array}$ & $\begin{array}{l}1.0754^{*} \\
(0.617)\end{array}$ & $\begin{array}{c}-3.7461^{* *} \\
(1.740)\end{array}$ & $\begin{array}{c}-5.0320^{* * *} \\
(0.484)\end{array}$ & $\begin{array}{c}18.387^{* * *} \\
(1.784)\end{array}$ \\
\hline \% HS Dropout 2000 & $\begin{array}{l}-0.2806 \\
(0.499)\end{array}$ & $\begin{array}{l}0.0433 \\
(1.384)\end{array}$ & $\begin{array}{l}0.9171^{* *} \\
(0.393)\end{array}$ & $\begin{array}{l}1.2939 \\
(1.430)\end{array}$ & $\begin{array}{r}-0.3847 \\
(0.501)\end{array}$ & $\begin{array}{l}0.0531 \\
(1.412)\end{array}$ & $\begin{array}{l}0.8863^{* *} \\
(0.393)\end{array}$ & $\begin{array}{l}1.3938 \\
(1.449)\end{array}$ \\
\hline$\%$ BA Degree 2000 & $\begin{array}{l}1.6715^{* * *} \\
(0.502)\end{array}$ & $\begin{array}{c}4.0842^{* * *} \\
(1.393)\end{array}$ & $\begin{array}{c}-3.3202^{* * *} \\
(0.395)\end{array}$ & $\begin{array}{c}16.094^{* * *} \\
(1.439)\end{array}$ & $\begin{array}{c}1.6376^{* * *} \\
(0.504)\end{array}$ & $\begin{array}{c}4.2651^{* * *} \\
(1.421)\end{array}$ & $\begin{array}{c}-3.3632^{* * *} \\
(0.395)\end{array}$ & $\begin{array}{c}15.886^{* * *} \\
(1.458)\end{array}$ \\
\hline Med Housing Value 2000 & $\begin{array}{c}-3.00 \mathrm{E}-06^{* * *} \\
(4.60 \mathrm{E}-07)\end{array}$ & $\begin{array}{c}-3.42 \mathrm{E}-06^{* * *} \\
(1.28 \mathrm{E}-06)\end{array}$ & $\begin{array}{l}-2.70 \mathrm{E}-06^{* * *} \\
(3.62 \mathrm{E}-07)\end{array}$ & $\begin{array}{l}6.39 \mathrm{E}-06^{* * *} \\
(1.32 \mathrm{E}-06)\end{array}$ & $\begin{array}{l}-3.01 \mathrm{E}-06^{* * *} \\
(4.62 \mathrm{E}-07)\end{array}$ & $\begin{array}{c}-3.43 \mathrm{E}-06^{* * *} \\
(1.30 \mathrm{E}-06)\end{array}$ & $\begin{array}{l}-2.60 \mathrm{E}-06^{* * *} \\
(3.62 \mathrm{E}-07)\end{array}$ & $\begin{array}{c}6.58 \mathrm{E}-06^{* * *} \\
(1.34 \mathrm{E}-06)\end{array}$ \\
\hline Property Crime Rate & $\begin{array}{c}3.84 \mathrm{E}-05 \\
(4.89 \mathrm{E}-05)\end{array}$ & $\begin{array}{c}-6.12 \mathrm{E}-04^{* * *} \\
(1.36 \mathrm{E}-04)\end{array}$ & $\begin{array}{l}-6.51 \mathrm{E}-05^{*} \\
(3.85 \mathrm{E}-05)\end{array}$ & $\begin{array}{c}7.64 \mathrm{E}-05 \\
(1.40 \mathrm{E}-04)\end{array}$ & $\begin{array}{c}3.97 \mathrm{E}-05 \\
(4.91 \mathrm{E}-05)\end{array}$ & $\begin{array}{l}-6.29 \mathrm{E}-04^{* * *} \\
(1.39 \mathrm{E}-04)\end{array}$ & $\begin{array}{l}-5.69 \mathrm{E}-05 \\
(3.85 \mathrm{E}-05)\end{array}$ & $\begin{array}{c}7.24 \mathrm{E}-05 \\
(1.42 \mathrm{E}-04)\end{array}$ \\
\hline API Elementary School & $\begin{array}{l}1.78 \mathrm{E}-03^{* * *} \\
(6.05 \mathrm{E}-04)\end{array}$ & $\begin{array}{l}-3.94 \mathrm{E}-03^{* *} \\
(1.68 \mathrm{E}-03)\end{array}$ & $\begin{array}{l}-1.74 \mathrm{E}-04 \\
(4.76 \mathrm{E}-04)\end{array}$ & $\begin{array}{c}-7.77 \mathrm{E}-03^{* * *} \\
(1.73 \mathrm{E}-03)\end{array}$ & $\begin{array}{l}1.74 \mathrm{E}-03^{* * *} \\
(6.07 \mathrm{E}-04)\end{array}$ & $\begin{array}{l}-3.95 \mathrm{E}-03^{* *} \\
(1.71 \mathrm{E}-03)\end{array}$ & $\begin{array}{l}-2.29 \mathrm{E}-04 \\
(4.76 \mathrm{E}-04)\end{array}$ & $\begin{array}{c}-7.96 \mathrm{E}-03^{* * *} \\
(1.76 \mathrm{E}-03)\end{array}$ \\
\hline API High School & $\begin{array}{l}5.44 \mathrm{E}-03^{* * *} \\
(6.53 \mathrm{E}-04)\end{array}$ & $\begin{array}{l}8.83 \mathrm{E}-03^{* * *} \\
(1.81 \mathrm{E}-03)\end{array}$ & $\begin{array}{l}-3.58 \mathrm{E}-04 \\
(5.14 \mathrm{E}-04)\end{array}$ & $\begin{array}{l}-1.02 \mathrm{E}-03 \\
(1.87 \mathrm{E}-03)\end{array}$ & $\begin{array}{l}5.35 \mathrm{E}-03^{* * *} \\
(6.55 \mathrm{E}-04)\end{array}$ & $\begin{array}{l}8.61 \mathrm{E}-03^{* * *} \\
(1.85 \mathrm{E}-03)\end{array}$ & $\begin{array}{l}-3.97 \mathrm{E}-04 \\
(5.14 \mathrm{E}-04)\end{array}$ & $\begin{array}{l}-8.83 \mathrm{E}-04 \\
(1.89 \mathrm{E}-03)\end{array}$ \\
\hline Constant & $\begin{array}{c}-3.7576^{* * *} \\
(0.521)\end{array}$ & $\begin{array}{c}-10.552^{* * *} \\
(1.445)\end{array}$ & $\begin{array}{c}3.5139^{* * *} \\
(0.410)\end{array}$ & $\begin{array}{c}-6.7992^{* * *} \\
(1.493)\end{array}$ & $\begin{array}{c}-3.6415^{* * *} \\
(0.523)\end{array}$ & $\begin{array}{c}-10.460^{* * *} \\
(1.475)\end{array}$ & $\begin{array}{c}3.5352^{* * *} \\
(0.410)\end{array}$ & $\begin{array}{c}-6.7514^{* * *} \\
(1.513)\end{array}$ \\
\hline Pseudo $\mathrm{R}^{2}$ & 0.1433 & 0.0450 & 0.2896 & 0.2512 & 0.1432 & 0.0451 & 0.2903 & 0.2515 \\
\hline Observations & 1,872 & 1,872 & 1,872 & 1,872 & 1,872 & 1,872 & 1,872 & 1,872 \\
\hline
\end{tabular}

Indicates significance at $10 \%\left({ }^{*}\right), 5 \%\left({ }^{* *}\right)$, and $1 \%\left({ }^{* * *}\right)$. Standard errors in parentheses. 
Table 8. Probit Model: Repeat Buyers by Move Type and Race/Ethnicity

\begin{tabular}{lcc}
\hline \hline & $\begin{array}{c}\text { Move Out } \\
\text { (Individual starts within 1 mile } \\
\text { radius and moves outside) }\end{array}$ & $\begin{array}{c}\text { Move In } \\
\text { (Individual starts outside 1 mile } \\
\text { radius and moves inside) }\end{array}$ \\
\hline Asian & $-0.175^{* * *}$ & $0.361^{* * *}$ \\
& $(0.0476)$ & $(0.0293)$ \\
Black & $-0.150^{* * *}$ & $0.362^{* * *}$ \\
& $(0.0693)$ & $(0.0461)$ \\
Hispanic & $-0.289^{* * *}$ & $0.468^{* * *}$ \\
& $(0.0394)$ & $(0.0256)$ \\
Income & $2.54 \mathrm{E}-06^{* * *}$ & $-1.84 \mathrm{E}-06^{* * *}$ \\
& $(3.11 \mathrm{E}-07$ & $(1.57 \mathrm{E}-07)$ \\
Constant & $0.243^{* * *}$ & $-0.882^{* * *}$ \\
& $(0.0440)$ & $(0.0242)$ \\
\hline Observations & 6,220 & 18,794 \\
\hline \hline
\end{tabular}

Indicates significance at $10 \%\left({ }^{*}\right), 5 \%\left(^{* *}\right)$, and $1 \%\left({ }^{* *}\right)$. Standard errors in parentheses. 
Table 9. Changes in Housing and Neighborhood Attributes Accompanying Move

\begin{tabular}{|c|c|c|c|c|c|c|c|}
\hline & & $\begin{array}{l}\text { Stayed } \\
\text { Inside }\end{array}$ & $\begin{array}{l}\text { Moved } \\
\text { Outside }\end{array}$ & Diff & $\begin{array}{l}\text { Stayed } \\
\text { Outside }\end{array}$ & $\begin{array}{l}\text { Moved } \\
\text { Inside }\end{array}$ & "Diff \\
\hline \multirow[t]{5}{*}{ Asian } & $\Delta$ Square Footage & 91 & 252 & 161 & -2 & -171 & -169 \\
\hline & $\Delta$ Prop Crime & -150 & -25 & 125 & -32 & 32 & 64 \\
\hline & $\triangle$ API Elem & -10 & 49 & 59 & 2 & -40 & -42 \\
\hline & $\triangle A P I H S$ & -11 & 20 & 31 & 3 & -12 & -15 \\
\hline & $\Delta$ Expenditure $(1,000 s)$ & 40 & 11 & -29 & 37 & -23 & -60 \\
\hline \multirow[t]{5}{*}{ Black } & $\Delta$ Square Footage & 172 & 209 & 37 & 80 & 25 & -55 \\
\hline & $\Delta$ Prop Crime & -159 & -27 & 132 & -49 & 21 & 70 \\
\hline & $\triangle A P I$ Elem & 25 & 8 & -17 & 11 & -40 & -51 \\
\hline & $\triangle A P I H S$ & 3 & -3 & -6 & 2 & -6 & -8 \\
\hline & $\Delta$ Expenditure $(1,000 s)$ & 62 & 88 & 26 & 12 & 21 & 9 \\
\hline \multirow[t]{5}{*}{ Hispanic } & $\Delta$ Square Footage & 35 & 137 & 102 & 70 & -102 & -172 \\
\hline & $\Delta$ Prop Crime & 68 & -160 & -228 & -26 & 184 & 210 \\
\hline & $\triangle$ API Elem & -7 & 62 & 69 & 9 & -56 & -65 \\
\hline & $\triangle A P I H S$ & -3 & 21 & 24 & 6 & -17 & -23 \\
\hline & $\Delta$ Expenditure $(1,000 s)$ & 19 & 67 & 48 & 44 & -10 & -54 \\
\hline \multirow[t]{5}{*}{ White } & $\Delta$ Square Footage & 133 & 254 & 121 & 103 & -73 & -176 \\
\hline & $\Delta$ Prop Crime & -11 & -43 & -32 & -11 & 59 & 70 \\
\hline & $\triangle A P I$ Elem & 5 & 38 & 33 & 3 & -18 & -21 \\
\hline & $\triangle A P I H S$ & -1 & -32 & 33 & 4 & -22 & -26 \\
\hline & $\Delta$ Expenditure $(1,000 s)$ & 51 & 93 & 42 & 59 & 2 & -57 \\
\hline
\end{tabular}


Figure 1. Location of TRI Sites in Los Angeles County Relative to Neighborhood Demographics: 2000

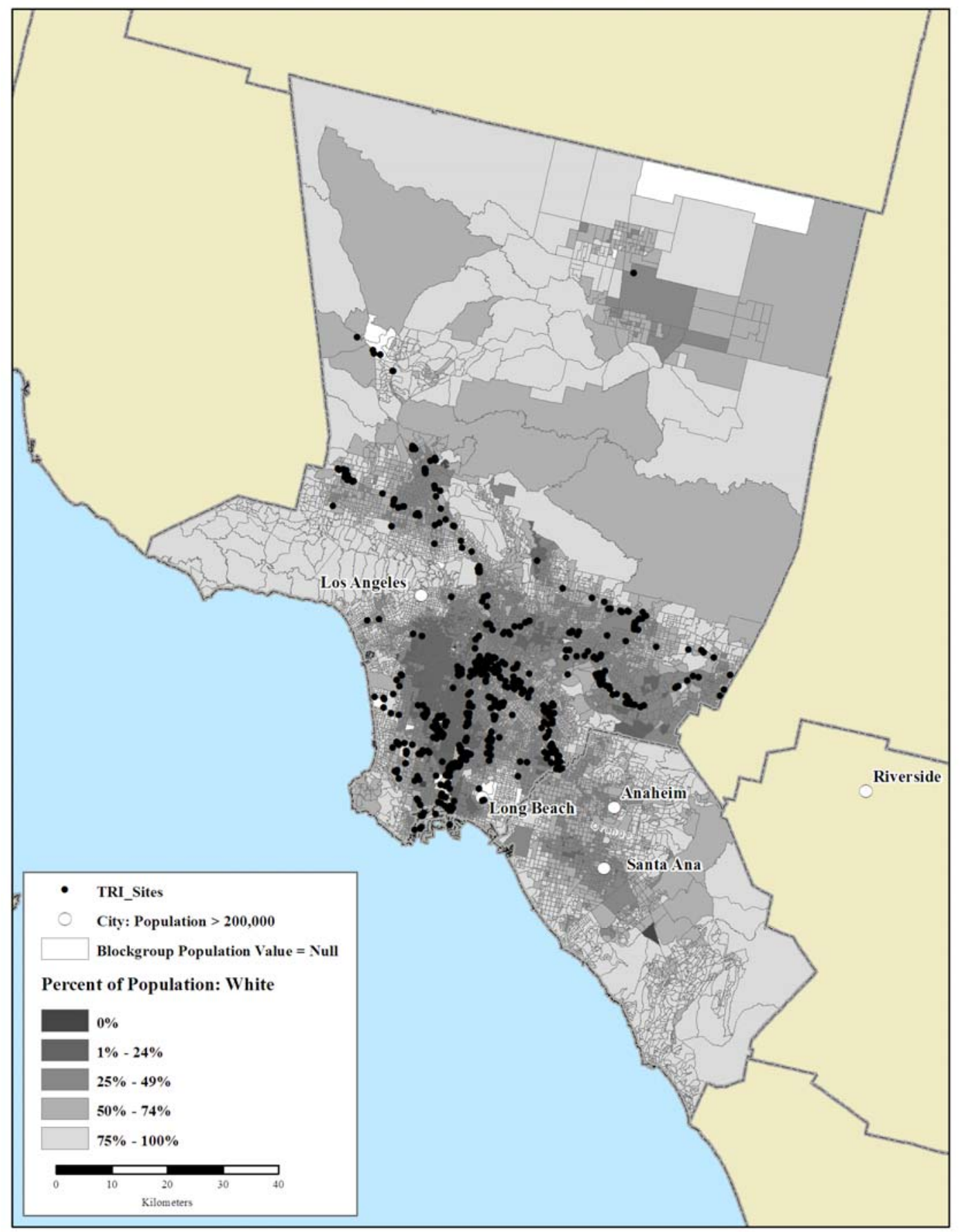


Figure 2. Location of TRI Sites in Los Angeles County Relative to Median Neighborhood Household Income: 2000

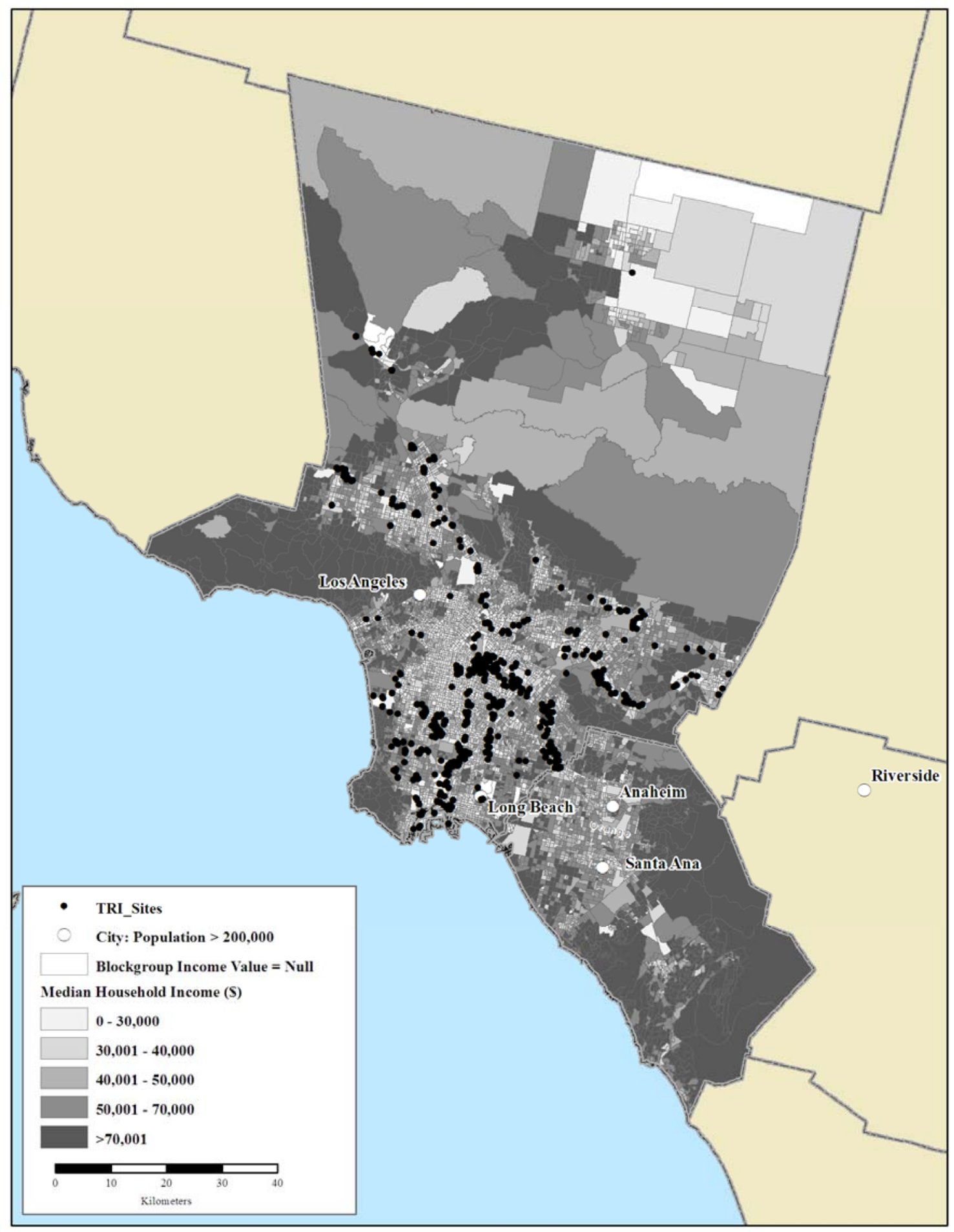


Figure 3. Share of Homebuyers Moving Within 1 Mile of a TRI Site

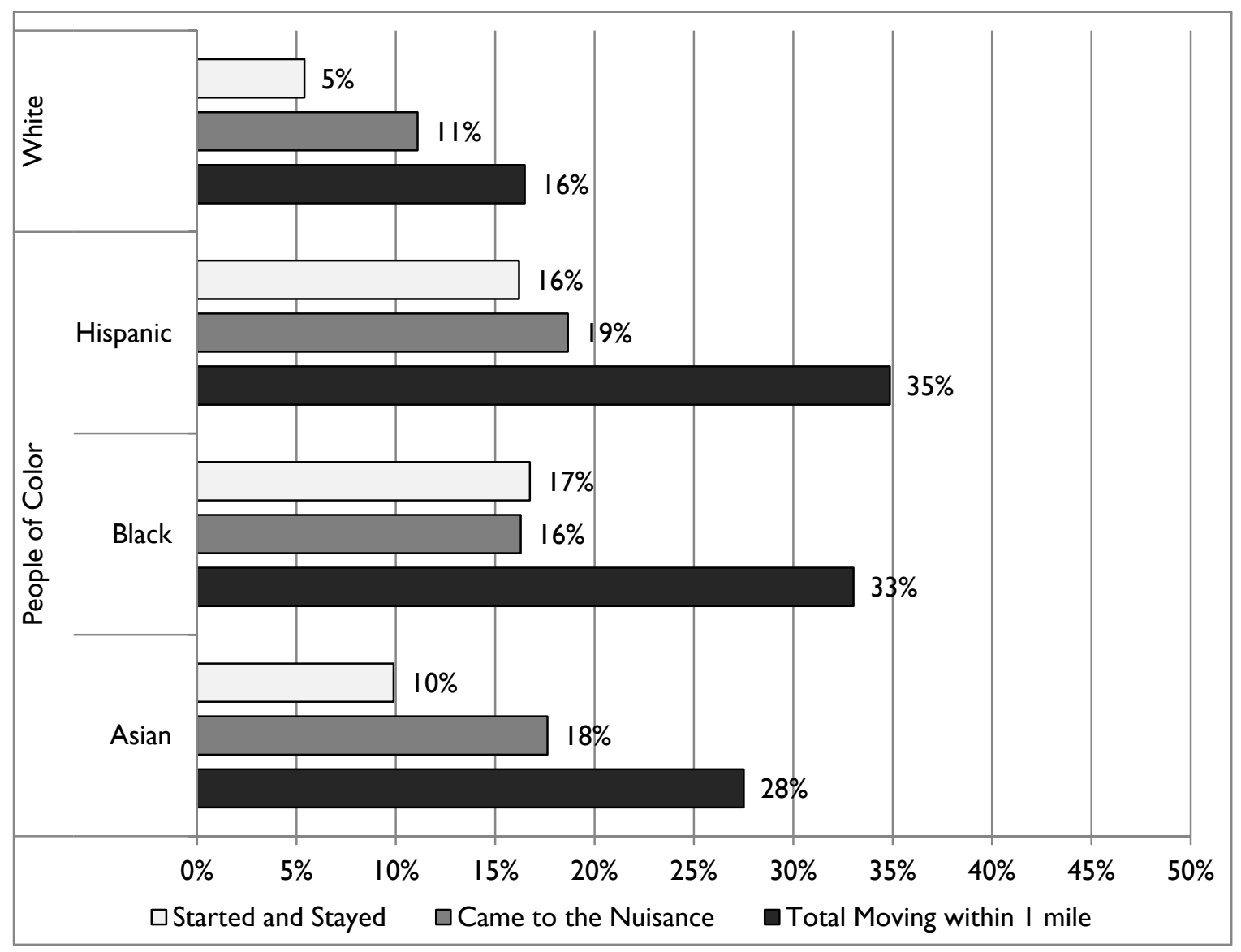


Figure 4. Plot of Mean Utility Estimates by Assumed $\rho$ Value, Whites

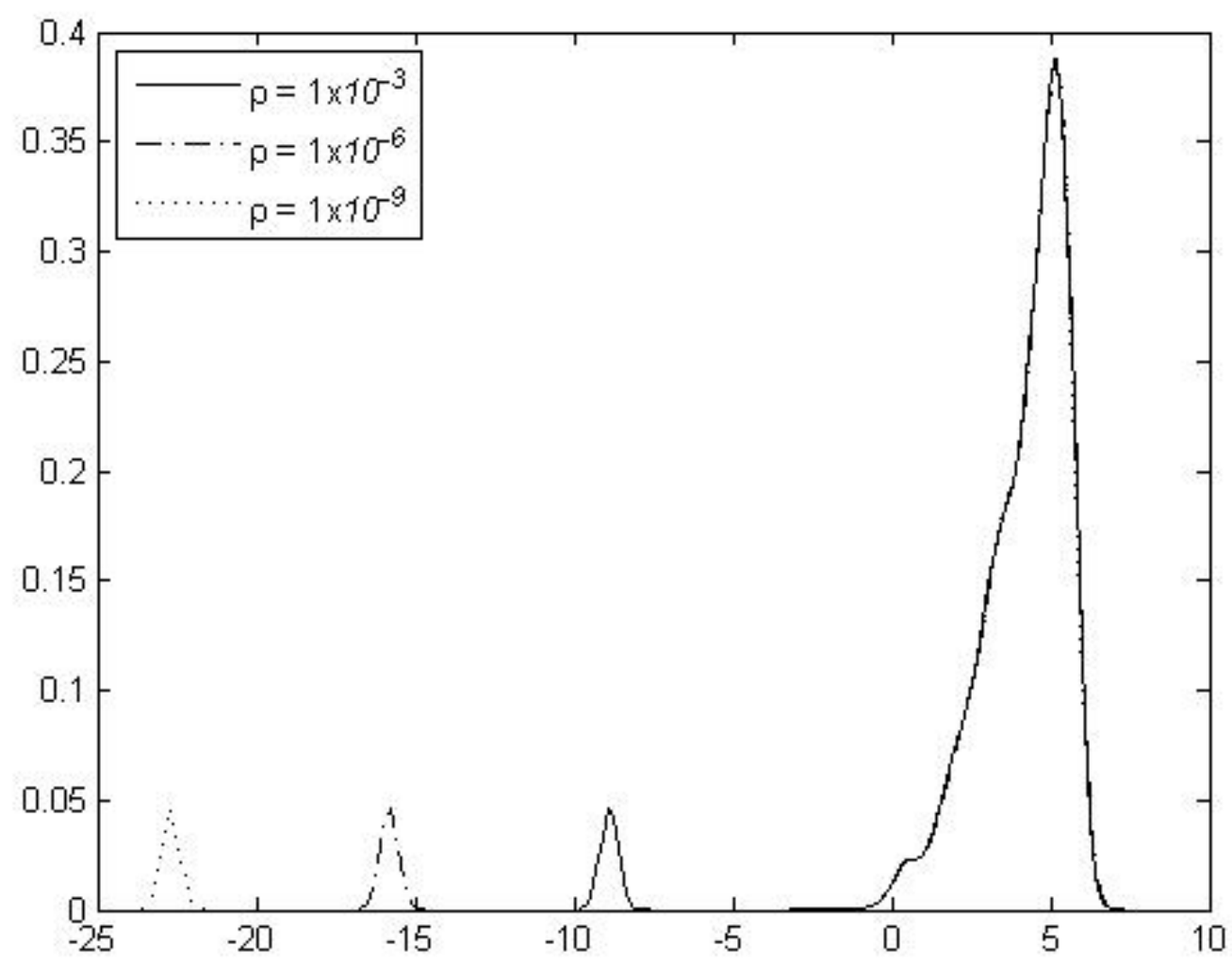


Figure 5: Mean Utilities and Amenity Values From Stylized Examples

(a) Example \#1 (Coming to the Nuisance)

(b) Example \#2 (Fleeing the Nuisance)

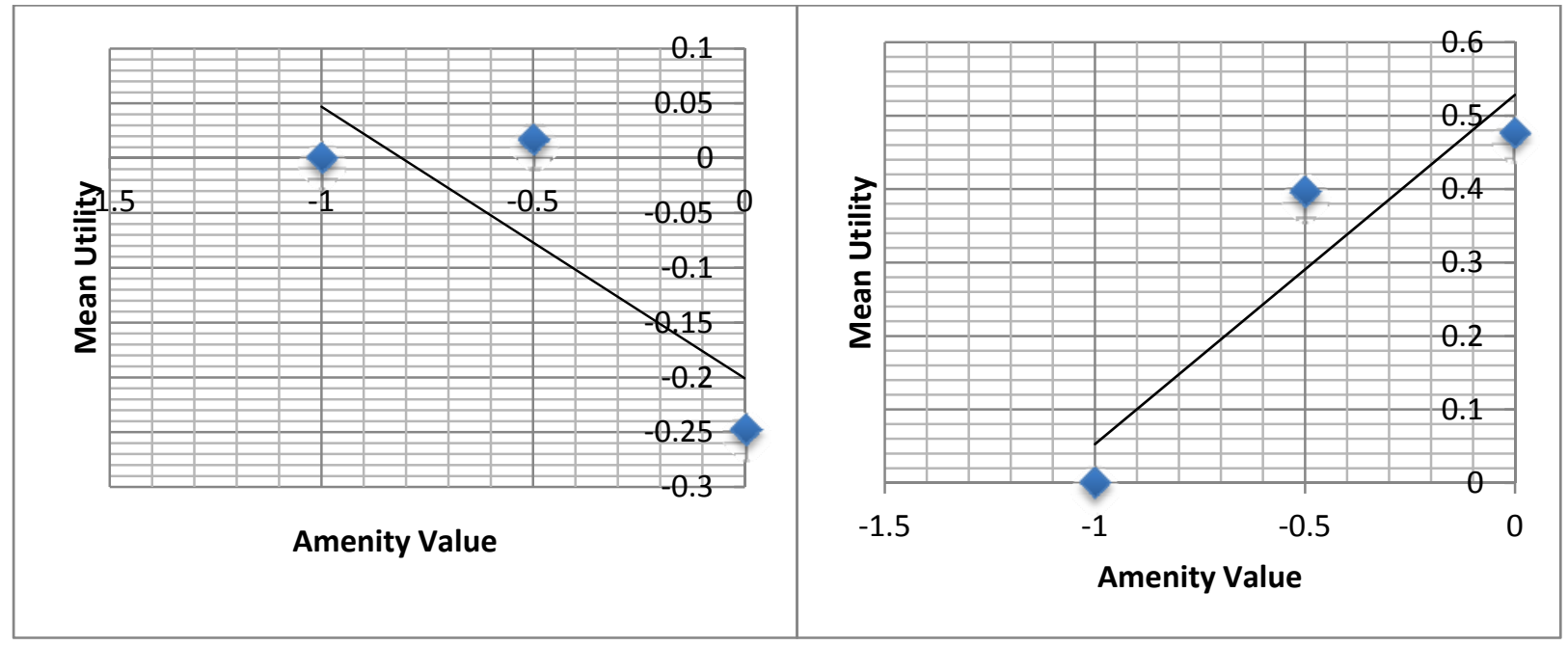

(c) Example \#3 (Coming to the Nuisance)

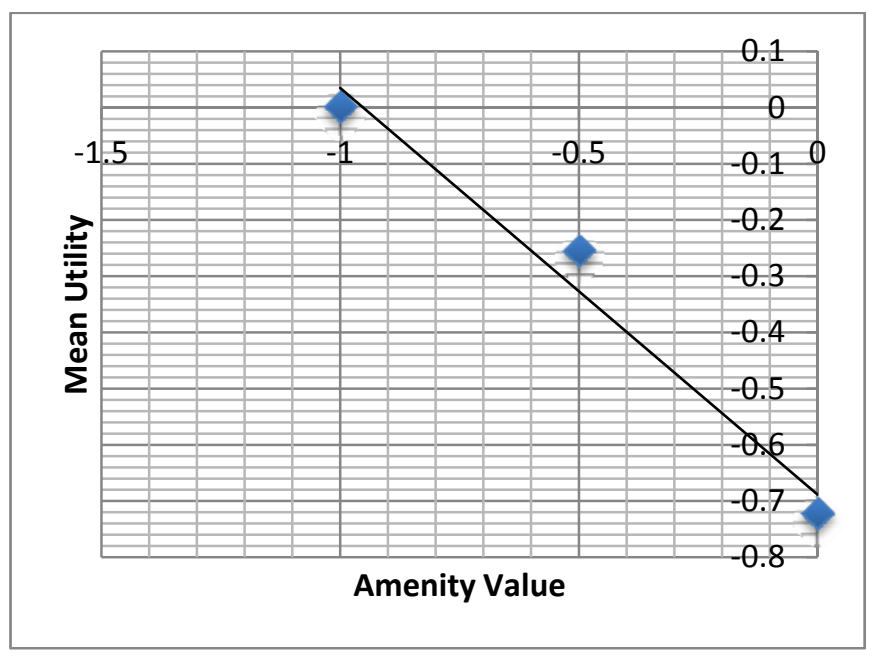




\section{Appendix}

Table A1. Structural Model of Market Dynamics, Median Regression Versus Least Squares, Linear Moving Distance, Alternative Sizes of Artificial Population "Patch", Whites, N =1,872

\begin{tabular}{|c|c|c|c|c|c|c|}
\hline & \multicolumn{2}{|c|}{$\rho=10^{-3}$} & \multicolumn{2}{|c|}{$\rho=10^{-6}$} & \multicolumn{2}{|c|}{$\rho=10^{-9}$} \\
\hline & $\begin{array}{c}\text { Median } \\
\text { Regression }\end{array}$ & Least Squares & $\begin{array}{l}\text { Median } \\
\text { Regression }\end{array}$ & Least Squares & $\begin{array}{l}\text { Median } \\
\text { Regression }\end{array}$ & Least Squares \\
\hline $\mathrm{TRI}_{2000}$ & $\begin{array}{c}-0.2573^{* * *} \\
(0.058)\end{array}$ & $\begin{array}{c}-0.3641^{* * *} \\
(0.049)\end{array}$ & $\begin{array}{c}-0.2573^{* * *} \\
(0.058)\end{array}$ & $\begin{array}{c}-0.3705^{* * *} \\
(0.055)\end{array}$ & $\begin{array}{c}-0.2573^{* * *} \\
(0.058)\end{array}$ & $\begin{array}{c}-0.3770^{* * *} \\
(0.064)\end{array}$ \\
\hline$\%$ Poverty $_{2000}$ & $\begin{array}{l}-0.0385 \\
(1.885)\end{array}$ & $\begin{array}{r}-1.6407 \\
(1.588)\end{array}$ & $\begin{array}{l}-0.0385 \\
(1.885)\end{array}$ & $\begin{array}{c}-3.6413^{* *} \\
(1.815)\end{array}$ & $\begin{array}{l}-0.0385 \\
(1.885)\end{array}$ & $\begin{array}{c}-5.6419^{* * *} \\
(2.101)\end{array}$ \\
\hline$\%$ Foreign Born 2000 & $\begin{array}{c}7.8585^{* * *} \\
(0.971)\end{array}$ & $\begin{array}{c}8.8615^{* * *} \\
(0.818)\end{array}$ & $\begin{array}{c}7.8585^{* * *} \\
(0.971)\end{array}$ & $\begin{array}{l}9.680^{* * *} \\
(0.935)\end{array}$ & $\begin{array}{c}7.8585^{* * *} \\
(0.971)\end{array}$ & $\begin{array}{c}10.498^{* * *} \\
(1.082)\end{array}$ \\
\hline$\%$ Female $\mathrm{HH}_{2000}$ & $\begin{array}{c}18.325^{* * *} \\
(1.761)\end{array}$ & $\begin{array}{c}14.758^{* * *} \\
(1.484)\end{array}$ & $\begin{array}{c}18.325^{* * *} \\
(1.761)\end{array}$ & $\begin{array}{c}14.592^{* * *} \\
(1.695)\end{array}$ & $\begin{array}{c}18.325^{* * *} \\
(1.761)\end{array}$ & $\begin{array}{c}14.426^{* * *} \\
(1.963)\end{array}$ \\
\hline$\%$ HS Dropout 2000 & $\begin{array}{l}1.2939 \\
(1.430)\end{array}$ & $\begin{array}{l}-0.1665 \\
(1.205)\end{array}$ & $\begin{array}{l}1.2939 \\
(1.430)\end{array}$ & $\begin{array}{l}-0.7618 \\
(1.376)\end{array}$ & $\begin{array}{l}1.2939 \\
(1.430)\end{array}$ & $\begin{array}{l}-1.357 \\
(1.594)\end{array}$ \\
\hline$\%$ BA Degree 2000 & $\begin{array}{c}16.094^{* * *} \\
(1.439)\end{array}$ & $\begin{array}{c}12.386^{* * *} \\
(1.212)\end{array}$ & $\begin{array}{c}16.094^{* * *} \\
(1.439)\end{array}$ & $\begin{array}{c}12.517^{* * *} \\
(1.385)\end{array}$ & $\begin{array}{c}16.094^{* * *} \\
(1.439)\end{array}$ & $\begin{array}{c}12.648^{* * *} \\
(1.603)\end{array}$ \\
\hline Med Housing Value $_{2000}$ & $\begin{array}{l}6.39 \mathrm{E}-06^{* * *} \\
(1.32 \mathrm{E}-06)\end{array}$ & $\begin{array}{l}4.64 \mathrm{E}-06^{* * *} \\
(1.11 \mathrm{E}-06)\end{array}$ & $\begin{array}{l}6.39 \mathrm{E}-06^{* * *} \\
(1.32 \mathrm{E}-06)\end{array}$ & $\begin{array}{l}4.24 \mathrm{E}-06^{* * *} \\
(1.27 \mathrm{E}-06)\end{array}$ & $\begin{array}{l}6.39 \mathrm{E}-06^{* * *} \\
(1.32 \mathrm{E}-06)\end{array}$ & $\begin{array}{l}3.84 \mathrm{E}-06^{* * *} \\
(1.47 \mathrm{E}-06)\end{array}$ \\
\hline Property Crime Rate & $\begin{array}{c}7.64 \mathrm{E}-05 \\
(1.40 \mathrm{E}-04)\end{array}$ & $\begin{array}{c}6.64 \mathrm{E}-05 \\
(1.18 \mathrm{E}-04)\end{array}$ & $\begin{array}{c}7.64 \mathrm{E}-05 \\
(1.40 \mathrm{E}-04)\end{array}$ & $\begin{array}{c}8.77 \mathrm{E}-05 \\
(1.35 \mathrm{E}-04)\end{array}$ & $\begin{array}{c}\text { 7.64E-05 } \\
(1.40 \mathrm{E}-04)\end{array}$ & $\begin{array}{c}1.09 \mathrm{E}-04 \\
(1.56 \mathrm{E}-04)\end{array}$ \\
\hline API Elementary School & $\begin{array}{c}-7.77 \mathrm{E}-03^{* * *} \\
(1.73 \mathrm{E}-03)\end{array}$ & $\begin{array}{c}-4.02 \mathrm{E}-03^{* * *} \\
(1.46 \mathrm{E}-03)\end{array}$ & $\begin{array}{c}-7.77 \mathrm{E}-03^{* * *} \\
(1.73 \mathrm{E}-03)\end{array}$ & $\begin{array}{l}-3.28 \mathrm{E}-03^{* *} \\
(1.67 \mathrm{E}-03)\end{array}$ & $\begin{array}{c}-7.77 \mathrm{E}-03^{* * *} \\
(1.73 \mathrm{E}-03)\end{array}$ & $\begin{array}{l}-2.55 \mathrm{E}-03 \\
(1.93 \mathrm{E}-03)\end{array}$ \\
\hline API High School & $\begin{array}{l}-1.02 \mathrm{E}-03 \\
(1.87 \mathrm{E}-03)\end{array}$ & $\begin{array}{c}2.28 \mathrm{E}-03 \\
(1.58 \mathrm{E}-03)\end{array}$ & $\begin{array}{l}-1.02 \mathrm{E}-03 \\
(1.87 \mathrm{E}-03)\end{array}$ & $\begin{array}{c}2.92 \mathrm{E}-03 \\
(1.80 \mathrm{E}-03)\end{array}$ & $\begin{array}{l}-1.02 \mathrm{E}-03 \\
(1.87 \mathrm{E}-03)\end{array}$ & $\begin{array}{l}3.56 \mathrm{E}-03^{*} \\
(2.08 \mathrm{E}-03)\end{array}$ \\
\hline Constant & $\begin{array}{c}-6.7992^{* * *} \\
(1.493) \\
\end{array}$ & $\begin{array}{c}-8.2315^{* * *} \\
(1.258) \\
\end{array}$ & $\begin{array}{c}-6.7992^{* * *} \\
(1.493) \\
\end{array}$ & $\begin{array}{c}-9.0622^{* * *} \\
(1.437) \\
\end{array}$ & $\begin{array}{c}-6.7992^{* * *} \\
(1.493) \\
\end{array}$ & $\begin{array}{c}-9.8929^{* * *} \\
(1.664) \\
\end{array}$ \\
\hline
\end{tabular}

Indicates significance at $10 \%\left({ }^{*}\right), 5 \%\left(^{* *}\right)$, and $1 \%\left({ }^{* *}\right)$. Standard errors in parentheses. 
Table A2. Structural Model of Market Dynamics (Median Regression), Logarithmic Moving Distance

\begin{tabular}{|c|c|c|c|c|c|c|c|c|}
\hline & $\delta_{j}^{\text {Asian }}$ & $\delta_{j}^{\text {Black }}$ & $\delta_{j}^{H i s p}$ & $\delta_{j}^{\text {White }}$ & $\delta_{j}^{\text {Asian }}$ & $\delta_{j}^{\text {Black }}$ & $\delta_{j}^{H i s p}$ & $\delta_{j}^{\text {White }}$ \\
\hline $\mathrm{TRI}_{2000}$ & $\begin{array}{c}-0.0858^{* * *} \\
(0.016)\end{array}$ & $\begin{array}{c}-0.0391^{*} \\
(0.020)\end{array}$ & $\begin{array}{l}-2.97 \mathrm{E}-03 \\
(7.63 \mathrm{E}-03)\end{array}$ & $\begin{array}{c}-0.0778^{* * *} \\
(0.012)\end{array}$ & & & & \\
\hline Avg TRI & & & & & $\begin{array}{c}-0.1018^{* * *} \\
(0.017)\end{array}$ & $\begin{array}{c}-0.0490^{* *} \\
(0.023)\end{array}$ & $\begin{array}{l}-4.58 \mathrm{E}-04 \\
(8.66 \mathrm{E}-03)\end{array}$ & $\begin{array}{c}-0.0811^{* * *} \\
(0.014)\end{array}$ \\
\hline$\%$ Poverty $_{2000}$ & $\begin{array}{c}-4.9271^{* * *} \\
(0.513)\end{array}$ & $\begin{array}{l}1.6384^{* *} \\
(0.664)\end{array}$ & $\begin{array}{l}0.4086 \\
(0.249)\end{array}$ & $\begin{array}{c}-2.2589^{* * *} \\
(0.396)\end{array}$ & $\begin{array}{c}-4.7986^{* * *} \\
(0.499)\end{array}$ & $\begin{array}{l}1.6613^{* *} \\
(0.661)\end{array}$ & $\begin{array}{l}0.4203^{*} \\
(0.249)\end{array}$ & $\begin{array}{l}-2.124^{* * *} \\
(0.398)\end{array}$ \\
\hline$\%$ Foreign Born 2000 & $\begin{array}{c}3.3544^{* * *} \\
(0.264)\end{array}$ & $\begin{array}{c}-3.6112^{* * *} \\
(0.342)\end{array}$ & $\begin{array}{c}-1.6836^{* * *} \\
(0.129)\end{array}$ & $\begin{array}{l}-0.0834 \\
(0.204)\end{array}$ & $\begin{array}{c}3.3792^{* * *} \\
(0.257)\end{array}$ & $\begin{array}{c}-3.6529^{* * *} \\
(0.340)\end{array}$ & $\begin{array}{c}-1.6766^{* * *} \\
(0.128)\end{array}$ & $\begin{array}{l}-0.1496 \\
(0.205)\end{array}$ \\
\hline$\%$ Female $\mathrm{HH}_{2000}$ & $\begin{array}{l}0.2519 \\
(0.479)\end{array}$ & $\begin{array}{c}1.7378^{* * *} \\
(0.620)\end{array}$ & $\begin{array}{c}-2.3471^{* * *} \\
(0.233)\end{array}$ & $\begin{array}{c}1.0580^{* * *} \\
(0.370)\end{array}$ & $\begin{array}{l}0.3399 \\
(0.466)\end{array}$ & $\begin{array}{c}1.7459^{* * *} \\
(0.617)\end{array}$ & $\begin{array}{c}-2.3450^{* * *} \\
(0.233)\end{array}$ & $\begin{array}{c}1.0304^{* * *} \\
(0.372)\end{array}$ \\
\hline$\%$ HS Dropout 2000 & $\begin{array}{l}-0.5160 \\
(0.389)\end{array}$ & $\begin{array}{l}0.4855 \\
(0.504)\end{array}$ & $\begin{array}{l}0.3509^{*} \\
(0.189)\end{array}$ & $\begin{array}{l}0.2155 \\
(0.300)\end{array}$ & $\begin{array}{l}-0.6161 \\
(0.378)\end{array}$ & $\begin{array}{l}0.4670 \\
(0.501)\end{array}$ & $\begin{array}{l}0.3499^{*} \\
(0.189)\end{array}$ & $\begin{array}{l}0.1513 \\
(0.302)\end{array}$ \\
\hline$\%$ BA Degree 2000 & $\begin{array}{c}1.4301^{* * *} \\
(0.391)\end{array}$ & $\begin{array}{c}1.4943^{* * *} \\
(0.507)\end{array}$ & $\begin{array}{c}-2.4233^{* * *} \\
(0.190)\end{array}$ & $\begin{array}{c}3.4934^{* * *} \\
(0.302)\end{array}$ & $\begin{array}{c}1.3961^{* * *} \\
(0.381)\end{array}$ & $\begin{array}{c}1.4220^{* * *} \\
(0.504)\end{array}$ & $\begin{array}{c}-2.4245^{* * *} \\
(0.190)\end{array}$ & $\begin{array}{c}3.5017^{* * *} \\
(0.304)\end{array}$ \\
\hline Med Housing Value $_{2000}$ & $\begin{array}{l}-2.57 \mathrm{E}-06^{* * *} \\
(3.58 \mathrm{E}-07)\end{array}$ & $\begin{array}{l}-3.73 \mathrm{E}-06^{* * *} \\
(4.64 \mathrm{E}-07)\end{array}$ & $\begin{array}{c}-1.49 \mathrm{E}-06^{* * *} \\
(1.74 \mathrm{E}-07)\end{array}$ & $\begin{array}{l}-2.56 \mathrm{E}-07 \\
(2.77 \mathrm{E}-07)\end{array}$ & $\begin{array}{l}-2.59 \mathrm{E}-06^{* * *} \\
(3.49 \mathrm{E}-07)\end{array}$ & $\begin{array}{l}-3.63 \mathrm{E}-06^{* * *} \\
(4.62 \mathrm{E}-07)\end{array}$ & $\begin{array}{c}-1.50 \mathrm{E}-06^{* * *} \\
(1.74 \mathrm{E}-07)\end{array}$ & $\begin{array}{l}-2.59 \mathrm{E}-07 \\
(2.78 \mathrm{E}-07)\end{array}$ \\
\hline Property Crime Rate & $\begin{array}{c}1.27 \mathrm{E}-05 \\
(3.81 \mathrm{E}-05)\end{array}$ & $\begin{array}{l}-6.99 \mathrm{E}-05 \\
(4.94 \mathrm{E}-05)\end{array}$ & $\begin{array}{l}-2.11 \mathrm{E}-05 \\
(1.86 \mathrm{E}-05)\end{array}$ & $\begin{array}{l}-5.40 \mathrm{E}-05^{*} \\
(2.94 \mathrm{E}-05)\end{array}$ & $\begin{array}{c}9.64 \mathrm{E}-07 \\
(3.71 \mathrm{E}-05)\end{array}$ & $\begin{array}{l}-7.30 \mathrm{E}-05 \\
(4.91 \mathrm{E}-05)\end{array}$ & $\begin{array}{l}-1.97 \mathrm{E}-05 \\
(1.85 \mathrm{E}-05)\end{array}$ & $\begin{array}{l}-5.39 \mathrm{E}-05^{*} \\
(2.96 \mathrm{E}-05)\end{array}$ \\
\hline API Elementary School & $\begin{array}{l}1.98 \mathrm{E}-03^{* * *} \\
(4.71 \mathrm{E}-04)\end{array}$ & $\begin{array}{c}2.14 \mathrm{E}-04 \\
(6.11 \mathrm{E}-04)\end{array}$ & $\begin{array}{c}3.18 \mathrm{E}-04 \\
(2.30 \mathrm{E}-04)\end{array}$ & $\begin{array}{l}-9.26 \mathrm{E}-05 \\
(3.64 \mathrm{E}-04)\end{array}$ & $\begin{array}{l}2.09 \mathrm{E}-03^{* * *} \\
(4.59 \mathrm{E}-04)\end{array}$ & $\begin{array}{c}1.68 \mathrm{E}-04 \\
(6.07 \mathrm{E}-04)\end{array}$ & $\begin{array}{c}3.25 \mathrm{E}-04 \\
(2.29 \mathrm{E}-04)\end{array}$ & $\begin{array}{c}1.07 \mathrm{E}-05 \\
(3.66 \mathrm{E}-04)\end{array}$ \\
\hline API High School & $\begin{array}{l}2.80 \mathrm{E}-03^{* * *} \\
(5.08 \mathrm{E}-04)\end{array}$ & $\begin{array}{c}3.66 \mathrm{E}-04 \\
(6.58 \mathrm{E}-04)\end{array}$ & $\begin{array}{c}3.61 \mathrm{E}-04 \\
(2.47 \mathrm{E}-04)\end{array}$ & $\begin{array}{l}2.12 \mathrm{E}-03^{* * *} \\
(3.92 \mathrm{E}-04)\end{array}$ & $\begin{array}{l}2.82 \mathrm{E}-03^{* * *} \\
(4.95 \mathrm{E}-04)\end{array}$ & $\begin{array}{c}4.17 \mathrm{E}-04 \\
(6.55 \mathrm{E}-04)\end{array}$ & $\begin{array}{c}3.97 \mathrm{E}-04 \\
(2.47 \mathrm{E}-04)\end{array}$ & $\begin{array}{l}2.10 \mathrm{E}-03^{* * *} \\
(3.94 \mathrm{E}-04)\end{array}$ \\
\hline Constant & $\begin{array}{c}-2.1653^{* * *} \\
(0.406)\end{array}$ & $\begin{array}{l}0.3629 \\
(0.526)\end{array}$ & $\begin{array}{c}0.7664^{* * *} \\
(0.198)\end{array}$ & $\begin{array}{c}-0.9540^{* * *} \\
(0.313)\end{array}$ & $\begin{array}{c}-2.2470^{* * *} \\
(0.395)\end{array}$ & $\begin{array}{l}0.3745 \\
(0.523)\end{array}$ & $\begin{array}{c}0.7327^{* * *} \\
(0.198)\end{array}$ & $\begin{array}{c}-1.0035^{* * *} \\
(0.315)\end{array}$ \\
\hline Pseudo $\mathrm{R}^{2}$ & 0.1317 & 0.0522 & 0.2971 & 0.2874 & 0.1318 & 0.0523 & 0.2970 & 0.2870 \\
\hline Observations & 1,872 & 1,872 & 1,872 & 1,872 & 1,872 & 1,872 & 1,872 & 1,872 \\
\hline
\end{tabular}

